\title{
Ostracoda (Crustacea) from Lizard Island, northern Great Barrier Reef, Australia. I. Families: Cytherellidae, Loxoconchidae, Cytherideidae, Cytheruridae, Paracytherideidae, Pectocytheridae, Krithidae, Cytheromatiidae, Bythocytheridae, Cytheridae
}

\author{
Patricia Behrens \\ Zoologisches Institut und Zoologisches Museum der Universität Hamburg; \\ Martin-Luther-King-Platz 3, D-W-2000 Hamburg 13, Federal Republic of Germany
}

\begin{abstract}
This paper deals with the taxonomy of the ostracod families Cytherellidae, Cytheridae, Cytheromatidae, Cytherideidae, Krithidae, Loxoconchidae, Paracytherideidae, Cytheruridae, Pectocytheridae and Bythocytheridae from the coral reefs around Lizard Island, northern Great Barrier Reef, Australia. 22 species belonging to these families were found. 7 species had been described from Australian coasts, 1 from the Red Sea and 1 with Indopacific-Westatlantic distribution. 9 species are newly described and 4 species remain in open nomenclature.
\end{abstract}

\section{INTRODUCTION}

This paper is part of an investigation on the taxonomy, biology and ecology of ostracods of the suborders Podocopa and Platycopa around Lizard Island, Great Barrier Reef. The author collected ostracods during 7 months from different biotopes around the island and in different seasons.

Knowledge on the benthic litoral Ostracoda of the Pacific area is sparse. The ostracod fauna of the northern tropical part including the Great Barrier Reef is virtually unknown. The podocopidan ostracods of the Great Barrier Reef are known mostly from the papers of Brady (1866, 1890), especially from the Challenger Expedition. Unfortunately, the descriptions of the species are incomplete and only carapaces are described. The first paper showing soft parts is by McKenzie (1967), dealing with Ostracoda from South Australia. Recently, Hartmann (1981) has dealt with ostracods from Heron Island, and Howe \& McKenzie (1989) with ostracods from Darwin and Western Australia. In his unpublished thesis (1977), Labutis reported on Cytheridea from the Southern Great Barrier Reef, mainly around Gladstone. Due to the lack of information, investigations from other geographical areas have formed the basis for this present study on Ostracoda from the northern Great Barrier Reef. These include the papers of Hartmann $(1978,1984$; Western Australia, Huahiné and Rangiroa), Yassini \& Jones (1987; Southeastern 
Australia), McKenzie (1986; SW Pacific), Cabioch et al. (1986; New Caledonia), and of Bentley (1988; Brisbane Water).

Lizard Island $\left(14^{\circ} 40^{\prime} \mathrm{S} ; 145^{\circ} 28^{\prime} \mathrm{E}\right)$ is a continental island in the northern tropical section of the Great Barrier Reef. It is located $36 \mathrm{~km}$ off the Queensland coast and only $16 \mathrm{~km}$ from the outer barrier reefs which mark the edge of the continental shelf (TextFig. 1). Lizard Island is fringed by a coral reef which also encompasses two nearby islands and encloses a lagoon of $10 \mathrm{~m}$ depth. Samples were taken in $0.5-16 \mathrm{~m}$ depth from different environments, including mangroves, sand flats, mud flats, seagrasses, dead coral fragments and algae. The sampling stations are shown in Text-Figure 1 and described in Table 1 . The water temperature range is between $25^{\circ} \mathrm{C}$ in June/July and $30^{\circ} \mathrm{C}$ in December/February. The salinity is $34 \mathrm{~S}$ during the whole year.

\section{MATERIALS AND METHODS}

Sediment samples were taken from $0.5-12 \mathrm{~m}$ depth by hand, using a handnet of $0.18 \mathrm{~mm}$ mesh, and either by snorkel or SCUBA diving. Coral fragments, algae or rocks were also collected by hand, put into a bucket filled with water and mixed with a few drops of $4 \%$ Formalin. The animals were washed and rubbed from the substrate and put into new water to keep them alive. In the laboratory, the living ostracods were picked out individually under a stereomicroscope and stored in vials with alcohol. The animals were dissected and the soft parts embedded in Polyvinyl-Lactophenol stained with Orange G. The left valves of about 5 specimens of each sex, if there was enough material, were measured under the microscope. Mean sizes are given in the text. Holotypes and some paratypic material are deposited at the Australian Museum, Sydney. Paratypes are also deposited at the Zoologisches Museum, Hamburg.

Abbreviations: $A M S=$ Australian Museum Sydney; $\mathrm{ZMH}=$ Zoologisches Museum Hamburg. $L V=$ left valve; $R V=$ right valve $; \mathrm{VM}=$ ventral margin $; \mathrm{DM}=$ dorsal margin; $\mathrm{AM}=$ anterior margin; $\mathrm{PM}$ = posterior margin; $\mathrm{Au}=$ antennula; $\mathrm{Aa}=$ antenna; $\mathrm{Md}=$ mandible; $\mathrm{Mxu}=$ maxillula; $\mathrm{P} 1=$ first walking leg (maxilla); P2 = second walking leg; P3 $=$ third walking leg, $1,2,3 \ldots$ = segments of the extremities, counted distadly.

\section{SYSTEMATIC DESCRIPTIONS}

Family Cytherellidae Sars, 1866

Subfamily Cytherellinae Sars, 1866

Genus Keijcyoidea Malz, 1981

Keijcyoidea poikilokosmena sp. $\mathbf{n}$.

Figs 1-6, Plate 1: Figs 1-5

\section{Material}

Hol otype: male, May 18, 1988, Lizard Island, Sta. 10, AMS.

Par a ty pes: Lizard Island: 1 female, August 24, 1989, Sta. $4 ; 1$ female, May 18, 1988, Sta. 11; AMS; 1 female, 1 male, August 16, 1989, Sta. 11; ZMH K-34571.

Locus typicus: Lizard Island, dead coral fragments. 

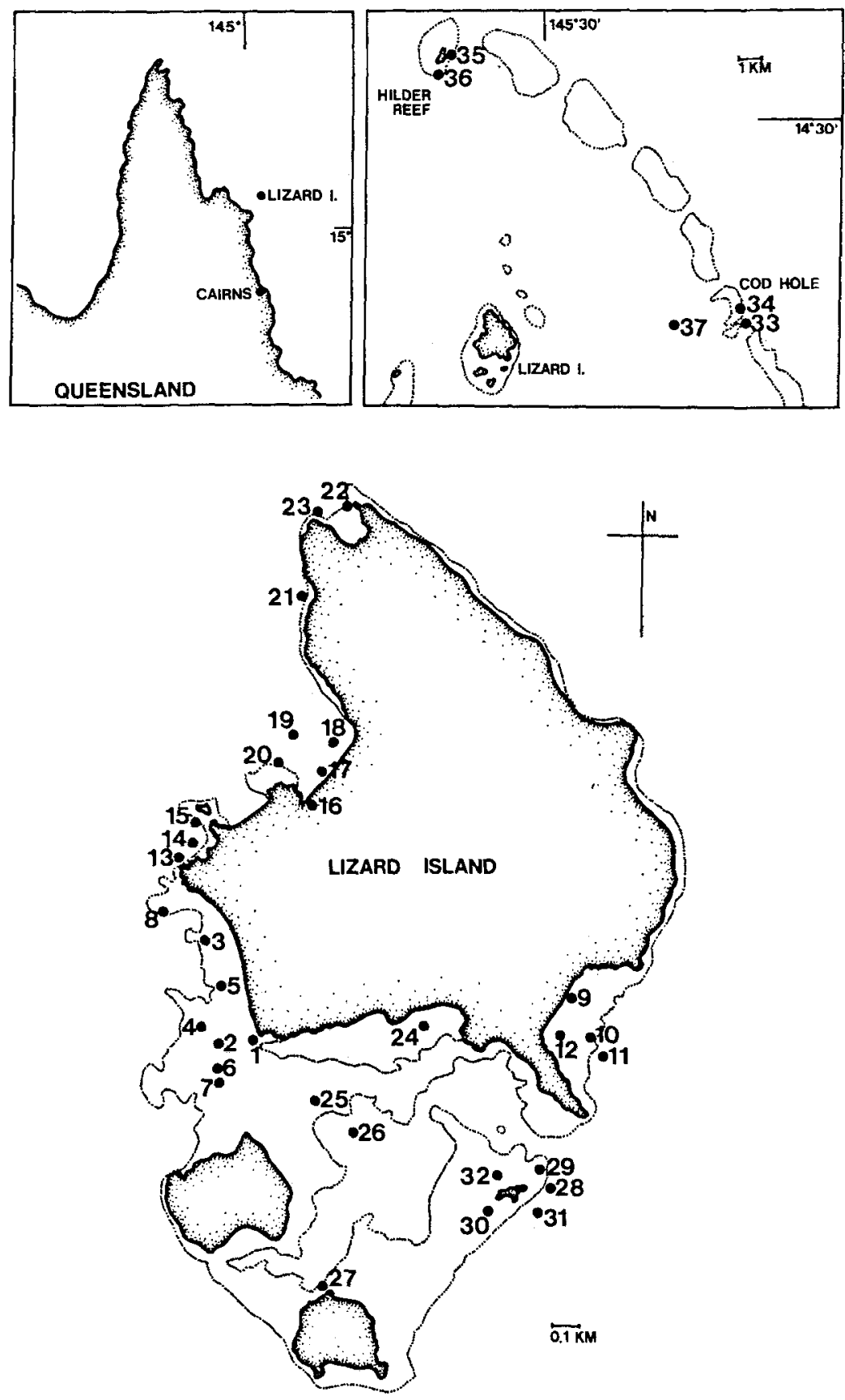

Text-Fig. 1. Map of Lizard Island showing positions of sampling stations 
Table 1. List of sampling stations

\begin{tabular}{|c|c|c|c|}
\hline Sta. & Location & Depth & Substrate \\
\hline 1 & Lagoon & $0.5 \mathrm{~m}$ & gravel \\
\hline 2 & Reef flat, leeward & $1.0 \mathrm{~m}$ & sand \\
\hline 3 & Reef flat, leeward & $0.5 \mathrm{~m}$ & sand between seagrass \\
\hline 4 & Reef flat, leeward & $0.5 \mathrm{~m}$ & dead coral fragments \\
\hline 5 & Reef flat, leeward & $0.5 \mathrm{~m}$ & calcareous algae (Halimeda sp.) \\
\hline 6 & Reef flat, leeward & $1.0 \mathrm{~m}$ & bluegreen algae (Hormothamnion sp.) \\
\hline 7 & Reef flat, leeward & $1.0 \mathrm{~m}$ & sand between algae \\
\hline 8 & Reef flat, leeward & $2.0 \mathrm{~m}$ & dead coral fragments \\
\hline 9 & Reef flat, windward & $0.5 \mathrm{~m}$ & shell sand \\
\hline 10 & Reef slope, windward & $2.0 \mathrm{~m}$ & dead coral fragments \\
\hline 11 & Reef slope, windward & $6.0 \mathrm{~m}$ & dead coral fragments \\
\hline 12 & Reef flat, windward & $1.0 \mathrm{~m}$ & red algae (Laurencia sp.) \\
\hline 13 & Reef flat, leeward & $3.0 \mathrm{~m}$ & dead coral fragments \\
\hline 14 & Reef flat, leeward & $3.0 \mathrm{~m}$ & red algae (Galaxaura sp.) \\
\hline 15 & Reef flat, leeward & $3.0 \mathrm{~m}$ & shell sand \\
\hline 16 & Mangroves & $1.0 \mathrm{~m}$ & fine sand \\
\hline 17 & Reef flat, leeward & $0.5 \mathrm{~m}$ & gravel \\
\hline 18 & Reef flat, leeward & $1.0 \mathrm{~m}$ & sand \\
\hline 19 & Reef flat, leeward & $3.0 \mathrm{~m}$ & seagrass \\
\hline 20 & Reef flat, leeward & $3.0 \mathrm{~m}$ & dead coral fragments \\
\hline 21 & Reef flat, leeward & $4.0 \mathrm{~m}$ & dead coral fragments \\
\hline 22 & Reef flat, leeward & $3.0 \mathrm{~m}$ & bluegreen algae (Micrococleus sp.) \\
\hline 23 & Reef flat, leeward & $5.0 \mathrm{~m}$ & dead coral fragments \\
\hline 24 & Lagoon & $0.5 \mathrm{~m}$ & fine sand \\
\hline 25 & Lagoon & $3.0 \mathrm{~m}$ & dead coral fragments \\
\hline 26 & Lagoon & $4.0 \mathrm{~m}$ & shéll sand \\
\hline 27 & Lagoon & $0.5 \mathrm{~m}$ & shell sand \\
\hline 28 & Reef slope, windward & $14.0 \mathrm{~m}$ & dead coral fragments \\
\hline 29 & Reef slope, windward & $3.0 \mathrm{~m}$ & dead coral fragments \\
\hline 30 & Reef flat, windward & $3.0 \mathrm{~m}$ & algae (Turbinara sp.) \\
\hline 31 & Reef slope, windward & $15.0 \mathrm{~m}$ & shell sand \\
\hline 32 & Reef slope, windward & $3.0 \mathrm{~m}$ & shell sand \\
\hline 33 & Outer reef & $15.0 \mathrm{~m}$ & shell sand \\
\hline 34 & Outer reef & $6.0 \mathrm{~m}$ & dead coral fragments \\
\hline 35 & Outer reef & $14.0 \mathrm{~m}$ & shell sand \\
\hline 36 & Outer reef & $14.0 \mathrm{~m}$ & dead coral fragments \\
\hline 37 & Outer reef & $16.0 \mathrm{~m}$ & dead coral fragments \\
\hline
\end{tabular}

Name: The greek words "poikilos" (= different) and "kosmena" (= ornament) refer to the differently ornamented right and left valves.

Description: The shell has its maximum height in the anterior half, declining to the posterior part. The VM is concave, the AM broadly rounded, and the PM ends in a blunt tip. The AM forms a wavy line. LV and RV have different carapace ornamentations. The LV has one row of larger fossae running parallel to the AM. That row is not developed in the RV. Hingement in the middle of the shell with inwardly directed extension. Au seven-segmented, with the following bristles: 1 laterally with one bristle, dorsodistally with two bristles and ventrodistally with one bristle. 3 ventrodistally with 
one short bristle. 4 and 5 dorsally with one claw and two bristles each, 4 ventrodistally with two long bristles. 6 dorsally with one claw and one bristle, ventrodistrally with one long bristle. 7 with one weakly developed claw, two bristles and one sensory stick. Aa at its basis dorsally with one long bristle, endopodite ventrally at the basis with two long bristles. 2 ventrally with one claw and two bristles, dorsally with one strong claw. 3 terminally with two bristles and one weak claw. Swimming bristles numerous. Palp of the Mxu with long segments, terminally with three bristles. Maxilla of the male threesegmented, ventrally with two bristles on 1 , laterally with four bristles on 2 . 3 dorsally with one bristle and terminally with one claw. Fu with 9 distally and 2 proximally directed bristles. Copulatory organ of the male triangular with long copulatory tube.

$\mathrm{Size}$ : females, LV: length $0.49 \mathrm{~mm}$, height $0.29 \mathrm{~mm}$; males, LV; length $0.46 \mathrm{~mm}$, height $0.27 \mathrm{~mm}$.

E colog : $K$. poikilokosmena was found on dead coral fragments.

Remarks: Due to its differentiated hingement, the systematic value of which is discussed by Malz (1981), the new species is placed in the genus Keijcyoidea. It resembles Cytherelloidea fijiensis (Brady, 1890) as illustrated by McKenzie (1986), but lacks the denticulation at the PM and the ridge running parallel to the dorsal margin in the posterior part of the shell. McKenzie also indicates a length of $0.55 \mathrm{~mm}$ for $C$. fijiensis, which is much larger than $K$. poikilokosmena sp. $\mathrm{n}$.

Family Cytheridae Baird, 1850

Subfamily Cytherinae Baird, 1850

Tribus Microcytherurini Hartmann, 1979

Genus Microcytherura G. W. Müller, 1894

Microcytherura aestuaricola Hartmann, 1980

Plate 1: Figs 6-9

Microcytherura aestuaricola Hartmann, 1980: 117-118, Figs 18-21, Plate 3: Figs 7-13.

Mate ri a l : Lizard Island: 34 females, 43 males, 19 larvae, August 3, 1989, Sta. 1; ZMH K-34572; 128 females, 160 males, 62 larvae, August 11, 1989, Sta. 17; AMS.

$\mathrm{Size}$ : females, LV: length $0.28 \mathrm{~mm}$, height $0.14 \mathrm{~mm}$; males, LV: length $0.30 \mathrm{~mm}$, height $0.14 \mathrm{~mm}$.

Ecology: The species lives seasonally on Lizard Island, and was found only during winter months; however, during these months in huge numbers in the sandy eulitoral.

Re m a rks: The individuals of the Lizard Island population are smaller in body size than those of the South and Southeast coast of Australia, where the females have a length of $0.29-0.32 \mathrm{~mm}$ and the males of $0.33-0.36 \mathrm{~mm}$ (Hartmann, 1980). 
Tribus Cytherini Baird, 1850

Genus Corallicythere Hartmann, 1974

?Corallicythere arcanis sp. $\mathrm{n}$.

Figs 7-13, Plate 1: Figs 10, 11, Plate 2: Figs 1-9

Material

Holotype: male, March 30, 1988, Cod Hole, Sta. 33; AMS.

Paraty pes: Lizard Island: 1 female, March 13, 1988, Sta. 26; 2 females, 4 males, September 2, 1989, Sta. 26; ZMH K-34573. Cod Hole: 10 females, 7 males, March 30 , 1988, Sta. 33; ZMH K-34573.

L ocus typicu s: Lizard Island, lagoon, shell sand.

$\mathrm{Name:}$ The latin word "arcanus" means mysterious.

Description: The DM of the shell is convex. The maximum height lies just in front of the middle. AM and PM are rounded, the VM is slightly concave in the region of the mouth. The shell of the female is larger than that of the male and serves as breeding chamber. The hingement is smooth. In its anterior part it is covered by small, spherical excrescences. These excrescences form ringlike structures around some of the pore canals. The eyecups are fused. Au six-segmented, 2 ventrodistally with one bristle, 3 and 4 dorsodistally with one short bristle each, 4 ventrodistally with one long bristle. 5 dorsodistally with two long bristles, ventrodistally with one long bristle. 6 terminally with one claw, two bristles and one sensory stick. Aa four-segmented with two short terminal claws, spinneret bristle three-segmented. 2 ventrodistally with one short bristle, 3 ventrally with two bristles and one sensory stick, dorsally with one long bristle. 3 more distally with one bristle. Respiratory plate of Md with three Strahlen, palp with very short bristles, no filter bristles developed. Mxu only with equally directed Strahlen. Walking leg P1 with one long anterior bristle, one kneebristle, one bristle distally at 2 and one long bristle at the posterior margin. P2 and P3 with bristles sirnilarly located, but the kneebristles more strongly developed. P3 with strong bristle at 2. Copulatory organ of the male with pointed side-capsule, copulatory tube circular.

$\mathrm{Siz}$ : females, LV: length $0.44 \mathrm{~mm}$, height $0.22 \mathrm{~mm}$; males, LV: length $0.38 \mathrm{~mm}$, height $0.19 \mathrm{~mm}$.

Ecology: The species was exclusively found in shell sand.

Remarks: ?Corallicythere arcanis sp. $\mathrm{n}$. lives in the interstitial system of coral sand, and displays morphological adaptations. Therefore, a systematic classification is difficult. The species differs from the Parvocytheridae, Cobanocytheridae and Psammocytheridae as it has three normally developed walking legs in both sexes. For the following characters, ?C. arcanis could be placed in the Cytherinae as well as in the Leptocytheridae: hingement, fused eyecups, respiratory plate with equally directed Strahlen, Aa with two terminal claws. The structure of the male's copulatory organ and the slight indication of a dorsoterminal angulation of the carapace are characters typical of the Leptocytheridae, but might be present in the Cytherinae as well. ?C. arcanis differs from the Leptocytheridae in the margin of the shell, which is thought to be a systematic character of high value. The Leptocytheridae have, as a commonly differentiated character, a broadly fused outer and inner lamella, with numerous marginal pore canals which are branched. The new species however has narrow fused lamellas and few marginal 
pore canals, which are not branched but single. Therefore, the species is assumed to belong to the Cytherinae, Tribus Cytherini, whose common character is the structure of the hingement. ?C. arcanis has several characters in common with Corallicythere verrucosa Hartmann, 1974 from the interstitial of the African coast. Both species have a similar marginal zone and have fused eyecups. They differ in the following characters: ?C. arcanis sp. n. has no caudal process such as that observed in $C$. verrucosa; the Au has six segments instead of five; the posterior part of the valve of the female serves as a breeding chamber; the male of $C$. verrucosa is larger. Knowledge on the interstitial species is meagre. Certainly, ?C. arcanis is more closely related to Corallicythere than to all the other described interstitial genera, which have derived in different families. On the other hand, provided that knowledge on interstitial species will increase in the future, the differences between both species may one day be interpreted on the level of genera. At the moment, the new species is, with reservation, placed to the Corallicythere.

Family Pectocytheridae Hanai, 1957

Genus Morkhovenia Teeter, 1975

Morkhovenia inconspicua (Brady, 1880) (Plate 4, Figs 9-10)

Cythere inconspicua Brady, 1880: 70, Plate 13: Figs 1a-d.

Morkhovenia inconspicua (Brady, 1880), - Teeter, 1975: 435, gen. nov.; Hartmann, 1984: 126 (Synonomie).

Materia l: Lizard Island: 3 females, 1 larva, August 24, 1989, Sta. 4; 1 larva, March 19, 1988, Sta. 6; 1 larva, May 18, 1988, Sta. 11; 1 female, May 10, 1988, Sta. 21; 1 female, August 14, 1989, Sta. 21; 1 female, August 12, 1989, Sta. 25; 2 females, 4 larvae, March 13, 1988, Sta. 26; 1 larva, September 2, 1989, Sta. 26; 1 female, August 17, 1989, Sta. 29; AMS. Cod Hole: 2 females, 2 larvae, March 30, 1988, Sta. 33; ZMH K-34574. Hilder Reef: 3 females, April 24, 1988, Sta. 35; 1 female, April 24, 1988, Sta. 36; ZMH K34574. Reef near Cod Hole: 1 larva, May 1, 1988, Sta. 37; ZMH K-34 574.

$\mathrm{S}$ iz e: females, LV: length $0.41 \mathrm{~mm}$, height $0.22 \mathrm{~mm}$.

Ecology: The species was found on dead coral fragments as well as on sandy substrates.

Remarks: The sizes of the individuals of the Lizard Island population resemble the largest sizes given by Hartmann (1981) for the population of Heron Island. The species has Indowestpacific-Westatlantic distribution.

\section{Genus Keijia Teeter, 1975}

Aenigmocythere Bonaduce, Masoli \& Pugliese 1976: 9.

Keijia hirundo (Bonaduce, Masoli \& Pugliese, 1976)

Plate 2: Figs 12, 13

Aenigmocythere hirundo Bonaduce, Masoli \& Pugliese, 1976: 380-382, Plate 4: Figs 6-11, TextFig. 4.

Pectocythere foveata Hartmann, 1978, - Yassini \& Jones, 1987: 826, Plate 14: Figs 12-13; non Hartmann, 1978. 
Materi a 1: Lizard Island: 1 female, August 24, 1989, Sta. 4; 2 females, August 8, 1989, Sta. 13; AMS; 1 female, August 12, 1989, Sta. 25; ZMH K-34575.

$\mathrm{S}$ i z e : females, LV: length $0.45 \mathrm{~mm}$, height $0.21 \mathrm{~m}$.

E colog y: The species was collected from dead coral fragments.

Remarks: The species coincides in all characters with the diagnostic features of the genus Keijia. Therefore, Aenigmocythere, as a monotypic genus, is synonymous with Keijia.

Keijia foveata (Hartmann, 1978)

Plate 3: Figs 1, 2

Pectocythere (?) foveata Hartmann, 1978: 144, Figs 619-620, Plate 14, Figs 12-13.

Keijia foveata (Hartmann, 1978), - Howe \& McKenzie, 1989: 32, new comb.

Mate ri a l: Hilder Reef: 1 female, 1 male, 1 larva, April 24, 1988, Sta. 35; AMS.

$\mathrm{Siz}$ : females, LV: length $0.49 \mathrm{~mm}$, height $0.22 \mathrm{~mm}_{\text {; }}$ males, LV: length $0.52 \mathrm{~mm}$, height $0.21 \mathrm{~mm}$.

Ecology: The species was found on shell sand in a depth of $15 \mathrm{~m}$.

$\mathrm{R} \mathrm{e} \mathrm{m} \mathrm{arks:} \mathrm{The} \mathrm{individuals} \mathrm{of} \mathrm{the} \mathrm{Hilder} \mathrm{Reef} \mathrm{population} \mathrm{are} \mathrm{smaller} \mathrm{compared} \mathrm{to}$ those of the Western Australia population, which are $0.53-0.55 \mathrm{~mm}$ in length (Hartmann, 1978). However, the sculpture of the carapace as well as the soft parts are identical with the description given by Hartmann.

Family Cytheromatidae Elofson, 1939

Subfamily Cytheromatinae Elofson, 1939

Genus Paracytheroma Juday, 1907

Paracytheroma aestatophila sp. $\mathrm{n}$.

Figs 14-20, Plate 3: Figs 5-10

Material

Holotype: male, March 10, 1988, Lizard Island, Sta. 3; AMS.

Parat y pes: Lizard Island: 1 male, March 10, 1988, Sta. 2; 80 females, 71 males, 42 larvae, March 10, 1988, Sta. 3; AMS; 2 females, August 23, 1989, Sta. 3; 1 male, March 15, 1988, Sta. 4 ; 5 females, 2 males, 4 larvae, March 15, 1988, Sta. 5; 1 male, March 19, 1988, Sta. 6; 5 females, 7 males, March 28, 1988, Sta. 7; 3 larvae, May 1, 1988, Sta. 18; 5 females, 3 males, 3 larvae, November 5, 1989, Sta. 18; ZMH K-34576.

Locus ty picus : Lizard Island, leeward side, sand.

N a m e: The greek words "aestas" (= summer) and "philein" (= to love) refer to the seasonal distribution of the species on Lizard Island.

Description: The carapace of the female is higher than that of the male, especially in the posterior part. The AM is rounded and proceeds in an almost straight DM that ends at an angle. The PM forms a caudal process, about half the height of the shell. The VM is straight, in the region of the mouth slightly concave; the VM of the 
female in the posterior part is slightly convex. The shell is smooth. There are about 50 marginal pore canals; the inner margin and line of concrescence only coincide in the region of the mouth. Hingement weak, with weak median bar and small anterior and posterior teeth in the LV. Au six-segmented, both terminal segments longer than segments 3 and 4.2 ventrodistally with one long bristle, 3 dorsodistally with one claw. 4 and 5 dorsodistally with one claw and ventrodistally with one strong bristle each. 6 terminally with one weak claw, one long bristle and one sensory stick. Aa foursegmented, with two terminal claws, of which only the dorsal one emerges from the terminal segment. Spinneret bristle three-segmented: 2 ventrodistally with one bristle, 3 distally with one of the terminal claws and one bristle, medioventrally two bristles and one sensory stick, laterally two bristles. Walking legs all with one long bristle at the posterior margin. P1 with two long bristles at the anterior margin, two kneebristles and one short bristle distally at 2. P2 with one long bristle at the anterior margin, one kneebristle and one long bristle at 2. P3 with one short anterior bristle, one kneebristle and one bristle at 2 , which is longer than the following segment. Copulatory organ of the male with large basal capsule, distally with a large chitinous clasp.

$\mathrm{S}$ i z e : females, LV: length $0.54 \mathrm{~mm}$, height $0.26 \mathrm{~mm}$; males, LV: length $0.54 \mathrm{~mm}$, height $0.24 \mathrm{~mm}$.

Ecology: The species lives in large populations in the sandy eulitoral among seagrass but was found only in April and May; then, however, in large numbers.

R e m a rk s : $P$. aestatophila sp. n. resembles $P$. caudata Hartmann, 1978 , but differs in the shape of the carapace and the structure of the male's copulatory organ.

Family Cytherideidae Sars, 1925

Subfamily Cytherideinae Sars, 1925

Tribus Cyprideidini Kollmann, 1960

Genus Cyprideis (Cyprideis) Jones, 1857

Cyprideis australiensis Hartmann, 1978

Plate 3: Figs 11, 12, Plate 4: Figs 1, 2

Cyprideis australiensis Hartmann, 1978: 85-86, Figs 147-155, Plate 5: Figs 1-5.

Material: Lizard Island: 9 females, 6 males, 4 larvae, May 8, 1988, Sta. 16; 6 females, 3 males, 1 larva, August 14, 1989, Sta. 16; AMS.

Size : females, LV: length $1.10 \mathrm{~mm}$; height $0.70 \mathrm{~mm}$; males, LV: length $1.10 \mathrm{~mm}$; height $0.60 \mathrm{~mm}$.

E cology : C. australiensis was found in brackish water (20 S) among mangroves in muddy sediment.

Re marks: The individuals of the west Australian population described by Hartmann (1978) were smaller in body size than those of the Lizard Island population (females LV 0.90-0.94 mm length, males LV 0.86-0.88 mm length), but the soft parts of the body as well as the characters of the shell correspond well in both populations. 
Family Krithidae Mandelstam, 1958

Subfamily Krithinae Mandelstam, 1958

Tribus Krithini Mandelstam, 1958

Genus Parakrithella Hanai, 1959

Parakrithella sp. Lizard 1

Plate 4: Fig. 3

Materia l: Lizard Island: 1 female, May 18, 1988, Sta. 11; AMS.

$\mathrm{Siz}$ e: females, $\mathrm{LV}$ : length $0.40 \mathrm{~mm}$, height $0.17 \mathrm{~mm}$.

E cology: One single female was found on dead coral fragments.

$\mathrm{Re} \mathrm{m}$ a r k s: The species differs in size as well as in shape from all other species of the genus, but remains in open nomenclature because of the insignificant material found.

\section{Parakrithella sp. Lizard 2}

Plate 4: Figs 4, 5

Material: Lizard Island: 1 female, August 8, 1989, Sta. 13; 1 female, 1 larva, August 5, 1989, Sta. 14; AMS.

$\mathrm{S}$ i z e : females, LV: length $0.47 \mathrm{~mm}$, height $0.22 \mathrm{~mm}$.

E cology: The species was found on red algae and dead coral fragments.

Remarks: The species resembles in size and shape of the shell Parakrithella australis McKenzie, 1967, but differs in the soft parts, especially in the palp of the Mxu and in the bristles of the walking legs. Because of the insignificant material, the species remains in open nomenclature.

Family Loxoconchidae Sars, 1925

Subfamily Loxoconchinae Sars, 1925

Genus Loxoconcha Sars, 1866

Loxocorniculum Benson \& Coleman 1963: 38.

Benson \& Coleman (1963) gave as the only diagnostic character to distinguish the genus Loxocorniculum from Loxoconcha the development of a posterodorsal protuberance. Because of the shape of the carapaces in the family, the posterodorsal part of the shell is distinctly developed with numerous transitions from a more strongly developed ridge to a prominent protuberance. These transitions can be observed even in closely related species. Therefore, the development of a posterodorsal protuberance does not possess the systematic value that would justify the introduction of a genus.

Loxoconcha georgei Hartmann, 1978

Plate 4: Figs 6-9

Loxoconcha georgei Hartmann, 1978: 259-268, Plate 9: Figs 13-16.

Loxocorniculum georgei (Hartmann, 1978), - Cabioch, Anglada \& Babinot, 1986: 28; Howe \& McKenzie, 1989: 24. 
Material: Lizard Island: 1 female, March 10, 1988, Sta. 3; 1 female, 1 larva, August 24, 1989, Sta. 4; 17 females, 13 males, 16 larvae, May 14, 1988, Sta. 8; 1 female, August 16, 1989, Sta. 12; 13 females, 2 males, 2 larvae, April 27, 1988, Sta. 13; 3 females, 1 male, 2 larvae, August 8, 1989, Sta. 13; 13 females, 5 larvae, May 3, 1988, Sta. 14; 7 females, 3 males, 2 larvae, August 5, 1989, Sta. 14; AMS. 11 females, 13 males, 13 larvae, May 10, 1988, Sta. 21; 3 females, 1 male, 3 larvae, August 14, 1989, Sta. 24; 1 female, August 15, 1989, Sta. 23; 3 females, May 17, 1989, Sta. 25; 2 females, August 12, 1989, Sta. 25; 1 female, August 17, 1989, Sta. 29; ZMH K-34577. Cod Hole: 1 female, August 7. 1989, Sta. 34; ZMH K-34577. Reef near Cod Hole: 1 female, May 1, 1988, Sta. 37; ZMH K34577.

Si z e : females, LV: length $0.50 \mathrm{~mm}$, height $0.33 \mathrm{~mm}$; males, LV: length $0.53 \mathrm{~mm}$, height $0.32 \mathrm{~mm}$.

E cology : L. georgei was found on dead coral fragments as well as on algae.

Remarks: Together with L. broomensis Hartmann, 1978 and L. minyaustralis Howe \& McKenzie, 1989, L. georgei belongs to a group of species which are closely related, all having quite similar shells. The species of the group can mainly be distinguished by their distinctly different soft parts. The population of Lizard Island differs from the one described by Hartmann in having two kneebristles on P1 instead of one. Both populations correspond in size.

Loxoconcha insulaecapricornensis Hartmann, 1981

Plate 4: Figs 10, 11, Plate 5: Figs 1, 2

Loxoconcha insulaecapricornensis Hartmann, 1981: 118-119, Figs 55-57, Plate 9: Figs 7-17.

Materia l: Lizard Island: 2 females, March 19, 1988, Sta. 6; 2 females, 1 larva, May 14, 1988, Sta. 8; 1 female, May 18, 1988, Sta. 11; 7 females, 2 larvae, September 17, 1989, Sta. 29; 1 female, 2 males, October 12, 1989, Sta. 30; 1 female, October 13, 1989, Sta. 31; AMS. Cod Hole: 11 females, 2 males, 7 larvae, August 7, 1989, Sta. 34; ZMH K34578. Hilder Reef: 1 female, 1 larva, April 24, 1988, Sta. 36; ZMH K-34578.

$\mathrm{Size}$ : females, LV: length $0.48 \mathrm{~mm}$; height $0.28 \mathrm{~mm}$; males, LV: length $0.55 \mathrm{~mm}_{i}$ height $0.34 \mathrm{~mm}$.

Ecology $:$ L. insulaecapricornensis was found only on dead coral fragments and algae at the windward side of the island.

Remarks: The individuals of the Lizard Island population are smaller than the populations of Rangiroa and Huahiné: females $0.51-0.53 \mathrm{~mm}$ long, males $0.56-0.57 \mathrm{~mm}$ long (Hartmann, 1984), and of Heron Island: females 0.53-0.57 mm long (Hartmann, 1981).

Loxoconcha heronislandensis Hartmann, 1981

Plate 5: Figs 3-6

Loxoconcha heronislandensis Hartmann, 1981: 117-118, Figs 52-54, Plate 9: Figs 1-6.

Mat e rial: Lizard Island: 1 female, March 7, 1988, Sta. 1; 1 larva, March 19, 1988, Sta. 6; 2 females, August 23, 1989, Sta. 6; 1 female, 1 larva, March 28, 1988, Sta. 7; 2 females, 1 larva, May 14, 1988, Sta. 8; 5 females, 3 males, 5 larvae, May 18, 1988, Sta. 11; 1 female, 2 males, 1 larva, August 16, 1989, Sta. 11; 6 females, 2 larvae, April 27, 1988 , Sta. 13; 3 females, August 8, 1989, Sta. 13; 8 females, 3 larvae, May 3, 1988, Sta. 14; AMS; 
2 females, 1 male, August 5, 1989, Sta. 14; 1 female, August 11, 1989, Sta. 20; 21 females, 12 larvae, May 19, 1988, Sta. 23; 2 females, August 15, 1989, Sta. 23; 1 female, 1 male, 3 larvae, May 17, 1988, Sta. 25; 2 females, April 1, 1988, Sta. 28; 6 females, 4 larvae, August 17, 1989, Sta. 29; 1 female, October 12, 1989, Sta. 30; 1 female, October 13, 1989, Sta. 31; 1 larva, October 13, 1989, Sta. 32 ; ZMH K-34579. Hilder Reef: 1 female, April 24, 1988, Sta. 36; ZMH K-34579. Reef near Cod Hole: 2 females, 7 males, 1 larva, May 1, 1988, Sta. 37; ZMH K-34579.

S i z e : females, LV: length $0.54 \mathrm{~mm}$, height $0.34 \mathrm{~mm}$; males, LV: length $0.56 \mathrm{~mm}$, height $0.33 \mathrm{~mm}$.

Ecology: Most specimens were collected from dead coral fragments, single specimens were also found on algae and sand.

$\mathrm{Re} \mathrm{m}$ a r k s: The individuals of the Lizard Island population are larger than those of the populations of Rangiroa and Huahiné: 0.50-0.53 mm length (Hartmann, 1984), and of Heron Island: 0.48-0.51 mm length (Hartmann, 1981).

\section{Loxoconcha violacea sp. $\mathrm{n}$.}

Figs 21-27, 34, Plate 5: Figs 7-10, Plate 6: Figs 1-4

\section{Material}

Hol ot y p e: male, March 13, 1988, Lizard Island, Sta. 26;AMS.

P a r a t y pe s: Lizard Island: 1 larva, March 10, 1988, Sta. 3; 1 male, March 15, 1988, Sta. 5; 1 male, May 18, 1988, Sta. 10; 1 female, April 27, 1988, Sta. 13; 1 male, August 8, 1989, Sta. 13; 1 male, 1 larva, May 1, 1988, Sta. 18; 1 female, November 5, 1989, Sta. 18; 17 females, 7 males, 13 larvae, March 13, 1988, Sta. 26; AMS; 1 female, 1 male, September 2, 1989, Sta. 26; 3 females, 2 males, 3 larvae, May 17, 1988, Sta. 27; ZMH K34580 .

L ocus ty picus: Lizard Island, lagoon, sand.

$\mathrm{N}$ a m e : The latin word "violaceus" means pink and refers to the colour of the living animal's shell.

Description: The shell of the female is higher in relation to the length than that of the male. The AM is broadly rounded. The VM is slightly concave in the region of the mouth but otherwise convex. The DM runs more or less in a straight line, slightly convex behind the eye. The VM has a selvage which extends to the middle of the PM, and gives the impression of a caudal process. The sculpture of the shell consists of fossae in the mid region. The pore canals are exposed in the posterior and anterior part, where the sculpture is smooth with some ridges. In the anterior part, there is a vestibule; in the posterior part the line of concrescence and the inner margin coincide. Hingement gongylodont. Au six-segmented, 4 and 5 only weakly subdivided. 2 ventrodistally with one hairy bristle, 3 and 4 dorsodistally with one claw each which bear very small sensory hairs at their ends. 5 dorsodistally with two bristles, ventrodistally with one bristle. 6 long, with very long terminal bristles. Aa four-segmented, spinneret bristle two-segmented, not longer than the terminal segment. 2 ventrodistally with one hairy bristle, 3 dorsodistally covered with hair, with one bristle. Medioventrally one bristle, ventrodistally one weakly developed claw. Last segment with two uniform terminal claws. Respiratory plate of the Md with four Strahlen, two of them long and hairy, two shorter. Bristles of the palp short, masticatory process with strong teeth. Respiratory plate of the Mxu with one long 
aberrant Strahl. Walking legs with bristles at the posterior margins. P1 with two bristles at the anterior margin of 1, two kneebristles and one bristle distally on 2. P2 and P3 with two bristles at the anterior margin of 1 , one kneebristle and one bristle distally on 2 .

$\mathrm{Siz}$ : females, LV: length $0.56 \mathrm{~mm}$, height $0.36 \mathrm{~mm}$; males, LV: length $0.62 \mathrm{~mm}$, height $0.34 \mathrm{~mm}$.

Ecology: The species lives mainly on sandy substrates; single specimens were found on dead coral fragments and algae.

Remarks : $L$. violacea sp. n. largely resembles $L$. judithae Howe \& McKenzie, 1989, but differs from it in the shape and the ornamentation of the shell. The transition from the VM to the PM is more steeply developed in $L$. judithae. Both posterior ridges of $L$. judithae run much closer together. There are no soft parts available of $L$. judithae to study the systematic relationship between both species, but they are probably closely related. The shape of the shell of $L$. violacea $\mathrm{sp}$. $\mathrm{n}$. is similar to that of $L$. gracilis (Brady, 1890 ), but the species can be distinguished by the ornamentation. The hingement of $L$. undulata Al-Furaih, 1984 differs from that of $L$. violacea sp. $n$. in having a smaller posterior tooth and different shape of the anterior socket in the right valve. L. batei Bate \& Gurney, 1981 has a DM which is more convex. L. abditocostata parva Hartmann, 1984 has a distinct dorsoterminal protuberance, which is not developed in $L$. violacea $\mathrm{sp} . \mathrm{n}$. The latter two species also differ in the structure of the male copulatory organs.

\section{Loxoconcha parahuahinéensis sp. $\mathrm{n}$.}

Figs 28-33, 35, Plate 6: Figs 5-12

Loxoconcha cf. fischeri minima Teeter, 1975, - Cabioch, Anglada \& Babinot, 1986: 28, Plate 10; Figs 3-6; non Teeter (1975).

\section{Material}

Hol ot y p e: male, May 3, 1988, Lizard Island, Sta. 14; AMS.

P a r a t y p e s: Lizard Island: 1 female, March 15, 1988, Sta. 5; 1 larva, May 18, 1988, Sta. 10; 3 females, 2 males, 2 larvae, May 18, 1988, Sta. 11; 1 female, May 3, 1988, Sta. 14; 1 female, August 5, 1989, Sta. 14; 2 larvae, May 16, 1988, Sta. 20; 2 females, 2 larvae, August 11, 1989, Sta. 20; 1 female, August 14, 1989, Sta. 21; 1 female, 1 larva, August 15, 1989, Sta. 23; 1 female, 2 males, May 17, 1988, Sta. 25; 1 female, August 12, 1989, Sta. 25; 1 female, March 13, 1988, Sta. 26; 1 larva, September 2, 1989, Sta. 26; 1 female, 1 male, 1 larva, April 1, 1988, Sta. 28; 1 female, 1 larva, August 17, 1989, Sta. 29; AMS. Cod Hole: 3 females, 5 males, 4 larvae, August 7, 1989, Sta. 34; ZMH K-34581. Reef near Cod Hole: 9 females, 2 males, May 1, 1988, Sta. 37; ZMH K-34581.

Locus typicus : Lizard Island, windward side, dead coral fragments.

Na me: The latin words "para" (= near to) in connection with "huahinéensis" refer to the resemblance of the species with $L$. huahinéensis Hartmann, 1984.

Description: The shell of the female is higher than that of the male in relation to the length. The DM is straight and ends in a posterodorsal protuberance. The VM of the female's shell is straight, whereas the VM of the male's shell is slightly convex in the posterior part. The AM bears five thorns of equal size, covered by a broad selvage. The VM in its transition to the PM bears four thorns which are less developed than the anterior ones. The PM ends in a caudal process. Eyecups are distinct. The ornamentation of the shell consists of deep fossae and ridges, some of the latter are very pronounced. 
Large wings protrude from either side of the shell. There are about 14 marginal pore canals. A small vestibule has developed in the anterior part; elsewhere the inner margin and line of concrescence coincide. Hingement gongylodont, strongly developed. Au fivesegmented, with the former segments 4 and 5 fused. 2 ventrodistally with one bristle, 4 ventrodistally with one long bristle and dorsodistally with one long and one short bristle. 5 terminally with one long and two shorter bristles. Aa four-segmented with two terminal claws. Spinneret bristle two-segmented. 2 ventrodistally with one hairy bristle, 3 medioventrally and mediodorsally with two bristles and distally with one weak claw. Md with respiratory plate and long teeth at the masticatory process. Mxu with aberrant Strahl. Walking legs with one bristle at the posterior margins of 1 , two bristles at the anterior margins of 1 and one bristle distally on 2. P1 with two kneebristles, P2 and P3 with one kneebristle each. The bristles of P3 are poorly developed.

$\mathrm{Siz}$ : : females, LV: length $0.53 \mathrm{~mm}$, height $0.33 \mathrm{~mm}$; males, LV: length $0.58 \mathrm{~mm}$, height $0.33 \mathrm{~mm}$.

Ecology: L. parahuahinéensis sp. $\mathrm{n}$. was collected from dead coral fragments, mainly in depths over $10 \mathrm{~m}$.

Remarks: L. parahuahinéensis sp. $\mathrm{n}$. is closely related to $L$. huahinéensis Hartmann, 1984. Both species differ in the following characters: The lateral wing-like processes of the shell are more developed in $L$. parahuahinéensis. The posterior margin of the shell of $L$. huahinéensis bears less thorns. One of the thorns is larger than the others. The more pronounced ridges of the sculpture lie in different positions in both species. The posterodorsal ridge has the same height as the anterodorsal ridge in $L$. huahinéensis, whereas the posterodorsal one extends higher than the anterodorsal one in L. parahuahinéensis. The soft parts differ in the $\mathrm{Au}$, in which the terminal segment is shorter and broader in $L$. parahuahinéensis. The segments 4 and 5 are not divided in $L$. huahinéensis. The basal capsule of the male's copulatory organ is larger, and the side capsule lacks some of the chitinous clasps in L. huahinéensis. L. fischeri minima Teeter, 1975 differs from $L$. parahuahinéensis in that it lacks a caudal process, and its PM declines more steeply.

Gattung Loxoconchella Triebel, 1954

Loxoconchella lizardensis sp. $\mathrm{n}$.

Figs 36-39, Plate 7 : Figs $1-3$

Material

Ho lot y pe: male, October 12, 1989, Lizard Island, Sta. 30; AMS.

Par a ty pe s: Lizard Island: 2 females, August 24, 1989, Sta. 4 ; 2 females, March 15, 1988, Sta. 5; 2 females, 2 larvae, August 4, 1989, Sta. $5 ; 7$ females, 3 larvae, August 23, 1989, Sta. 6; AMS; 1 female; August 8, 1989, Sta. 13; 1 female, May 3, 1988, Sta. 14; 1 female, August 5, 1989, Sta. 14; 2 females, 1 larva, October 12, 1989, Sta. 30; ZMH $\mathrm{K}-34582$

L ocus ty picu s: Lizard Island, algae.

$\mathrm{N}$ a $\mathrm{m}$ e: The species name refers to Lizard Island.

Description: The VM of the shell is straight. The DM rises from the distinct eyecup posteriorly. It declines behind the lateral protuberance and ends in a caudal process. The lateral protuberance is on the same level as the caudal process. The 
sculpture of the shell consists of fossae, which are small and reticulate at the margins and larger towards the middle. There are 22 marginal pore canals and also numerous false marginal pore canals. The latter are highly branched. The inner margin and line of concrescence mostly coincide. The hingement consists of a smooth bar. Au corresponds with that of L. pulchra McKenzie, 1967. Aa four-segmented with two terminal claws, spinneret bristle two-segmented, not longer than the terminal claw. 2 ventrodistally with one bristle, 3 medioventrally and mediodorsally with two bristles each, ventrally, but more distally located, one bristle. Md corresponds with that of $L$. pulchra, but the inner bristle of the palp is not so strong and not hairy. Mxu with well developed aberrant bristle at the respiratory plate. Walking legs in relation to the whole body very long. $P 1$ with two bristles at the anterior margin, two kneebristles and one bristle distally at 2 . Posterior margin with one bristle. P2 with two bristles at the anterior margin, one kneebristle, one bristle distally at 2 and one bristle at the posterior margin. P3 with one kneebristle and one bristle distally at 2 . Fu with three bristles.

Size: females, LV: length $0.53 \mathrm{~mm}$, height $0.39 \mathrm{~mm}$.

(The valves of the single male found were destroyed.)

E cology: L. lizardensis sp. n. was found on algae and dead coral fragments.

Remarks: L. lizardensis sp. $n$. belongs to a group of species with a lateral protuberance of the shell. There are very few data on the soft parts of the genus; only those of $L$. pulchra and $L$. dorsobullata Hartmann, 1964 have been investigated. The species show as diagnostic soft part characters a furca bearing three bristles and a reduction of bristles at P3. The copulatory organ of the male has the same elongated structure. Regarding the characters of the shell, they differ in having the lateral protuberance which $L$. pulchra lacks. The shell of $L$. scottoi Bonaduce, Masoli, Minichelli \& Pugliese, 1980 differs in shape from that of L. lizardensis sp. n. in having angular transitions in the posterior dorsal and ventral parts and in having a larger protuberance. L. dorsobullata differs in the line of the dorsal margin, which does not decline in its posterior part. In L. anomala (Brady, 1880), the lateral protuberance is located more in the middle of the shell, whereas in $L$. lizardensis sp. n. more dorsally. The protuberance of $L$. ishizaki Keji, 1978 is less prominent than that of $L$. lizardensis sp. $\mathrm{n}$.

Family Paracytherideidae Puri, 1957

Genus Paracytheridea (Paracytheridea) G. W. Müller, 1894

Paracytheridea gynaikokratia sp. n.

Figs 40-43, Plate 7: Figs 4-9

Material

Ho lotype: female, April 27, 1988, Lizard Island, Sta. 13; AMS.

P a r a ty pe s: Lizard Island: 1 larva, March 15, 1988, Sta. 5; 1 female, 1 larva, May 14, 1988, Sta. 8; 1 larva, May 18, 1988, Sta. 10; 2 females, 2 larvae, May 18, 1988, Sta. 11; 4 females, 7 larvae, August 16, 1989, Sta. 11; 2 females, April 27, 1988, Sta. 13; 2 females, 1 larva, August 8, 1989, Sta. 13; 1 female, August 5, 1989, Sta. 14; 2 females, 2 larvae, August 11, 1989, Sta. 20; 2 females, May 10, 1988, Sta. 21; 1 female, 1 larva, August 14, 1989, Sta. 21; 1 larva, May 19, 1988, Sta. 23; 1 female, 1 larva, August 15, 1989, Sta. 23; AMS; 3 females, 1 larva, August 12, 1989, Sta. 25; 2 females, 5 larvae, August 17, 1989, 
Sta. 29; ZMH K-34583. Hilder Reef: 1 female, 1 larva, April 24, 1988, Sta. 36; ZMH $\mathrm{K}-34583$.

L o cus typicus: Lizard Island, windward side, dead coral fragments.

Na m e: The greek word "gynaikokratia" (= ruled by women) refers to the fact that males were not found.

Description: The DM of the shell declines posteriorly, interrupted by irregular bulges. In its posterior part, the DM is obscured by strong ridges. The PM ends in a long caudal process. The AM is rounded and undulated, which results from ridges coming from the posterior middle of the shell. The VM is straight; it is obscured by ventrally located lateral wing-like protuberances. There is no vestibule. The hingement is complicated, with taxodont bar. Au six-segmented, 2 ventrodistally with one long bristle, 3 dorsodistally with one short bristle, 4 dorsodistally with two bristles, ventrodistally with one bristle. 5 dorsodistally with two bristles, ventrodistally with one bristle. 6 with two bristles and one sensory stick. Aa resembles that of $P$. remanei Hartmann, 1964. Respiratory plate of the Md with one Strahl. Walking legs with the following bristles: P1 with two bristles at the anterior margin, the distal one strongly developed, two kneebristles and one at 2. Posterior margin with one bristle. P2 and P3 each with two bristles at the anterior margin of 1 , one kneebristle and one bristle at 2 .

Size: females, LV: length $0.51 \mathrm{~mm}$, height $0.25 \mathrm{~mm}$.

E colog y : P. gynaikokratia sp. n. was mainly collected from dead coral fragments; single specimens were found on macroalgae.

Remarks: $P$. gynaikokratia sp. $n$. is closely related to $P$. remanei, but differs in shape and ornamentation of the carapace. The differences can be seen distinctly from the dorsal view, $P$. gynaikokratia has a notch between the posterior and anterior part of the lateral wing, which is not developed in $P$. remanei. $P$. gynaikokratia lacks eyecups which are clearly present in $P$. remanei. $P$. aqabaensis Bonaduce, Masoli \& Pugliese, 1976 also differs in the shape of the carapace, especially in the shape of the lateral wings which do not have a notch. Eyecups are also developed. P. pseudoremanei Bonaduce, Masoli, Minichelli \& Pugliese, 1980 has eyecups and a shorter caudal process. Paracytheridea sp. Holden, 1976 from Hawait differs in the lateral wing which is smaller. P. longicaudata (Brady, 1890) differs in the ornamentation, especially in the ridges.

\section{Paracytheridea sp. Lizard 1}

Plate 7: Fig. 10

Material: Lizard Island: 1 female, August 17, 1989, Sta. 29; AMS. Cod Hole: 1 female, August 7, 1989, Sta, 34; AMS.

$\mathrm{Size}$ : females, LV: length $0.52 \mathrm{~mm}$, height $0.22 \mathrm{~mm}$

Ecology: The species was found twice on dead coral fragments from the windward side.

Re m a r ks: The species differs from all other species of the genus in the ornamentation of the shell. As it is not possible to describe the species sufficiently on the basis of the two females found, it will remain in open nomenclature. 
Family Cytheruridae G. W. Müller, 1894

Subfamily Cytherurinae, G. W. Müller, 1894

Genus Cytherura Sars, 1866

Cytherura cf. densuireticulata Hartmann, 1978

Plate 7: Figs 11, 12

Cytherura densuireticulata Hartmann, 1978: 109-110, Figs 309-318, Plate 10: Figs 15-18.

Material: Lizard Island: 1 female, March 7, 1988, Sta. 1; 11 females, 2 larvae, August 3, 1989, Sta. 1; 1 female, March 10, 1988, Sta. 2; 3 females, 2 larvae, March 10 , 1988, Sta. 3; 1 male, August 23, 1989, Sta. 3; AMS; 2 larvae, August 23, 1989, Sta. 6; 1 female, March 28, 1988, Sta. 7; 1 female, August 12, 1989, Sta. 27; 1 female, April 1, 1988, Sta. 28; ZMH K-34584.

Si ze: females, LV: length $0.38 \mathrm{~mm}$, height $0.29 \mathrm{~mm}_{\text {; }}$

(The valves of the single maie found were destroyed.)

Ecology: Cytherura cf. densuireticulata was found in the sandy upper sublitoral.

Remarks: A large variability can be found in some characters of the species. The male of the Lizard Island population bears a pointed process at its side whereas the population of Western Australia bears a rounded one (Hartmann, 1978). Hartmann mentioned a large variability, but could not split up the different varieties into species. The ornamentation of the shell also shows a close relationship to $C$. tenuifossulata Hartmann, 1978. Unfortunately, no soft parts of that species have been studied yet, which could give necessary information.

\section{Genus Hemicytherura Elofson, 1941 \\ Hemicytherura viridiminor sp. $\mathrm{n}$.}

Figs 44-49, Plate 8; Figs 1-4

Material

Holotype: female, May 14, 1988, Lizard Island, Sta. 8; AMS.

P a r a ty pes: Lizard Island: 1 female, March 15, 1988, Sta. 4; 2 females, March 15, 1988, Sta. $5 ; 2$ females, March 19, 1988, Sta. 6 ; 8 females, May 14, 1988, Sta. $8 ; 1$ female, May 18, 1988, Sta. 11; 1 female, August 16, 1989, Sta. 11; 1 female, April 27, 1988, Sta. 13; 3 females, August 8, 1989, Sta. 13; 1 female, August 5, 1989, Sta. 14; 3 females, 1 larva, May 10, 1988; Sta. 21; 3 females, August 14, 1989, Sta. 21; 1 female, May 19, 1988, Sta. 23; AMS; 2 females, March 13, 1988, Sta. 26; ZMH K-34585. Hilder Reef: 7 females, April 24, 1988, Sta. 36; ZMH K-34585. Reef near Cod Hole: 1 female, May 1, 1988, Sta. 37; ZMH K-34585.

Locus typicus: Lizard Island, dead coral fragments.

Na m e: The Latin words "viridis" (= green) and "minor" (= small) refer to size and colour of the shell.

Description: The RV is higher and shorter than the LV, its upper AM slightly concave. The DM extends in a convex line, with its posterior section obscured by a dorsoterminal protuberance. The PM ends in a pointed caudal process. The posterior part of the VM is also obscured by a protuberance. The AM bears six thorns and a broad 
selvage. The ornamentation of the shell consists of fossae and ridges. One ridge runs parallel with the VM, but is interrupted in the area of the muscle scars. The ridges have a reticulated structure. There are about 23 marginal pore canals; a small vestibule is developed in the anterior part. Elsewhere, inner margin and line of concrescence coincide. Hingement merodont. Au six-segmented. 2 ventrodistally with one bristle, 3 and 4 dorsodistally with one bristle each, 5 ventrodistally and dorsodistally with one bristle, 6 with three bristles. Aa five-segmented with two terminal claws, spinneret bristle three-segmented. 2 and 3 ventrodistally with one bristle each, 3 dorsodistally with one bristle and terminally with one claw. Md with strong masticatory process, bearing four teeth and a very small palp. Mxu with one aberrant Strahl. P1 with one bristle at the anterior margin, two kneebristles, one bristle distally at 2 and a long bristle at the posterior margin. P2 corresponding, but with only one kneebristie. P3 only with one kneebristle and one bristle at 2.

$\mathrm{S}$ i z e: females, LV: length $0.35 \mathrm{~mm}$, height $0.20 \mathrm{~mm}$.

E c o log y: $H$. viridiminor $\mathrm{sp.} \mathbf{n}$. was found on different substrates including algae, sand and dead coral fragments.

Remarks: Only one male was found, but that was subadult. The shape of the carapace shows resemblance with Hemicytherura sp. Yassini \& Jones, 1987. However, Hemicytherura sp. Yassini \& Jones does not have a dorsoterminal protuberance but a horizontal ridge. $H$. videns (Müller, 1894) differs in having a longer caudal process and more prominent protuberances in the posterior part of the shell.

\section{Genus Semicytherura Wagner, 1957 \\ Semicytherura sp. Lizard 1}

Plate 8: Figs 5, 6

Materia l: 3 females, August 17, 1989, Lizard Island, Sta. 29; AMS.

Si ze : females, LV: length $0.35 \mathrm{~mm}$, height $0.17 \mathrm{~mm}$.

Ecology: All three females were found on dead coral fragments.

Re mark s: The species is closely related to $S$. kaethehoffmannae Hartmann, 1979, S. geraldtonensis Hartmann, 1978, S. cryptifera (Brady, 1880), and Semicytherura sp. Hartmann, 1984. Parallel to the dorsal margin there is an anterior ridge which is present in all species, but can hardly be found in Semicytherura sp. Lizard 1. All species have very similar carapace ornamentations but differ in their soft parts, especially in the structure of the copulatory organs of the males. Due to these problems, a name has not been assigned to the species.

Family Bythocytheridae Sars, 1926

Genus Bythocythere Sars, 1866

Bythocythere arenicola sp. $\mathrm{n}$.

Figs 50-55, Plate 8: Figs 7-12

Material

Hol otype: male, October 13, 1989, Lizard Island, Sta. 31; AMS. 
Par atypes: 1 female, 1 larva, October 13, 1989, Lizard Island, Sta. 31; AMS. 2 females, October 13, 1989, Lizard Island, Sta. 31; ZMH K-34586.

L ocus ty picus: Lizard Island, sand.

Name: The latin words "arena" ( $=$ sand) and "colere" (= to live) refer to the habitat of the species.

Description: The carapace of the female is higher in the posterior part than that of the male. The DM is straight and ends in a dorsoterminal angulation. The AM is rounded, the VM slightly convex. The PM forms a caudal process in its upper part. Eyecups are missing. The sculpture is reticulate. There are wing-like protuberances in the posteroventral part of the shell. The hingement consists of a smooth bar. Au sevensegmented, with long and slender segments. 2 dorsally and ventrally with one bristle each, dorsodistally with one bristle. 3 dorsodistally with one bristle, 4 laterally with two bristles, 5 dorsodistally with two and ventrodistally with one bristle. 7 terminally with two long and one shorter bristles. Aa with three terminal claws, spinneret bristle twosegmented. 2 ventrodistally with two bristles, 3 ventrally as well as dorsally with two short bristles, ventrodistally with one bristle. One small bristle besides the terminal claws. Respiratory plate of the Md with five Strahlen. Mxu with four aberrant Strahlen at the respiratory plate. Walking leg $\mathrm{P} 1$ with two long bristles at the anterior margin, two kneebristles and one bristle each at 2 and 3 , at the posterior margin a respiratory plate with four Strahlen. P2 with one long bristle at the anterior margin, one kneebristle and one bristle at 2 and 3 each. One long bristle at the posterior margin. P3 with very small kneebristle, one bristle at 2 and one very strong bristle at 3 . Fu with three bristles. Copulatory organ of the male with rounded basal capsule and very long side capsule.

S i z e : females, LV: length $0.40 \mathrm{~mm}$, height $0.23 \mathrm{~mm}$; males, LV: length $0.42 \mathrm{~mm}$, height $0.24 \mathrm{~mm}$.

E cology: The species was found only once, on sandy substrate.

$\mathrm{R} \mathrm{e} \mathrm{m} \mathrm{a} \mathrm{r} \mathrm{k} \mathrm{s} \mathrm{:} \mathrm{The} \mathrm{shape} \mathrm{of} \mathrm{the} \mathrm{carapace} \mathrm{as} \mathrm{well} \mathrm{as} \mathrm{the} \mathrm{sculpture} \mathrm{of} B$. arenicola sp. $\mathrm{n}$. differentiate it from all other species in the genus.

Acknowledgements. I would like to thank Prof. Dr. G. Hartmann for proposing the subject of this investigation and for his encouragement during the progress of the study. Thanks are also due to $\mathrm{J}$. Kirch and $\mathrm{O}$. Gross for assistance in collecting the material, to $\mathrm{R}$. Walter for technical assistance and to $\mathrm{H}$. Petersen for nomenclature indication. S. Meyer corrected the English of the manuscript. These studies were supported by the Amalie Dietrich Fellowship 1988 of the Australian Museum, Sydney, and the article is based on a doctoral study in the Faculty of Biology, University of Hamburg.

\section{LITERATURE CITED}

Al-Furaih, A. A. F., 1984. On Loxoconcha undulata Al-Furaih sp. nov. - Stereo-atlas ostracod shells $11,103-106$.

Bate, R. H. \& Gurney, A., 1981. The ostracod genus Loxoconcha Sars from Abu Dhabi Lagoon and the neighbouring near-shore shelf, Persian Gulf. - Bull. Br. Mus. nat. Hist. (Zool.) 41, 235-251.

Benson, R. H. \& Coleman, G. L., 1963. Recent marine Ostracods from the eastern Gulf of Mexico. Univ. of Kansas paleont. Contr. (Arthropoda) 1963 (2), 1-52.

Bentley, C., 1988. Podocopid Ostracods of Brisbane Water, Near Sydney, South-Eastern Australia. In: Evolutionary biology of Ostracoda. Ed. by T. Hanai, N. Ikeya \& K. Ishizaki. Kodansha, Tokyo, $439-449$.

Bonaduce, G., Masoli, M. \& Pugliese, N., 1976. Ostracoda from the Gulf of Aqaba (Red Sea). - Pubbl. Staz. zool. Napoli 40, 372-428. 
Bonaduce, G., Masoli, M., Minichelli, G. \& Pugliese, N., 1980. Some new benthic marine ostracod species from the Gulf of Aqaba (Red Sea). - Boll. Soc. paleont. ital. 19, 143-178.

Brady, G. S., 1866. On new or imperfectly known species of marine Ostracoda. - Trans. zool. Soc. London 5, 359-393.

Brady, G. S., 1880. Report on the Ostracoda dredged by H.M.S. Challenger during the years 1873-1876. - Zoology 1, 1-184.

Brady, G. S., 1890. On Ostracoda collected by H. B. Brady, Esq., L.L.D., F.R.S., in the South Sea Islands. - Trans. R. Soc. Edinb. 35, 489-525.

Cabioch, G., Anglada, R. \& Babinot, J.-F., 1986. Microfaunes et paléoenvironments des récifs frangeants quaternaires de Mamié et Ricaudy (Nouvelle-Calédonie). - Cah. Micropaléont. 1, 5-36.

Hartmann, G., 1964. Zur Kenntnis der Ostracoden des Roten Meeres. - Kieler Meeresforsch. 20, $35-127$

Hartmann, G., 1974. Zur Kenntnis des Eulitorals der afrikanischen Westküste zwischen Angola und Kap der Guten Hoffnung und der afrikanischen Ostküste von Südafrika und Moçambique unter besonderer Berücksichtigung der Polychaeten und Ostracoden. Teil 3. Die Ostracoden des Untersuchungsgebietes. - Mitt. hamb. zool. Mus. Inst. 69 (Erg.Bd), 229-520.

Hartmann, G., 1978. Die Ostracoden der Ordnung Podocopida G. W. Müller, 1894 der tropischsubtropischen Westküste Australiens (zwischen Derby im Norden und Perth im Süden). - Mitt. hamb. zool. Mus. Inst. 75, 63-219.

Hartmann, G., 1979. Die Ostracoden der Ordnung Podocopida G. W. Müller, 1894 der warmtemperierten (antiborealen) West- und Südwestküste Australiens (zwischen Perth im Norden und Eucla im Süden). - Mitt. hamb. zool. Mus. Inst. 76, 219-301.

Hartmann, G., 1980. Die Ostracoden der Ordnung Podocopida G. W. Müller, 1894 der warmtemperierten und subtropisch-tropischen Küstenabschnitte der Süd- und Südostküste Australiens (zwischen Ceduna im Westen und Lake Entrance im Osten). - Mitt. hamb. zool. Mus. Inst. 77, 111-204.

Hartmann, G., 1981. Die Ostracoden der Ordnung Podocopida G. W. Müller, 1894 der subtropischtropischen Ostküste Australiens (zwischen Eden im Süden und Heron Island im Norden). - Mitt. hamb. zool. Mus. Inst. 78, 97-149.

Hartmann, G., 1984. Zur Kenntnis der Ostracoden der polynésischen Inseln Huahiné (Gesellschaftsinseln) und Rangiroa (Tuamotu-Inseln). - Mitt. hamb. zool. Mus. Inst. 81, 117-169.

Holden, J. C., 1976. Late cenozoic Ostracoda from Midway Island drill holes, - Prof. Pap. geol. Surv. $680-F, 1-43$.

Howe, H. V. \& McKenzie, K. G., 1989. Recent marine Ostracoda (Crustacea) from Darwin and NorthWestern Australia. - Northern Territory Mus. Arts Sci. Monogr. Ser. 3, 1-50.

Keji, A. J., 1978. Remarks on the Indo-Pacific ostracode genus Loxoconchella. - Proc. K. ned. Akad. Wet. (B) $81,215-229$.

Malz, H., 1981. Paläozäne Ostracoden von den Emperor Seamounts, NW-Pazifik. - Zitteliana 7. $3-29$.

McKenzie, K. G., 1967. Recent Ostracoda from Port Phillip Bay, Victoria. - Proc. R. Soc. Vict. 80, 61-106.

McKenzie, K. G., 1986. A comparative study of collections from the SW Pacific (Saipan to Tonga), with the description of Gambiella caudata (Brady, 1890) and a new species of Pterobairdia (Ostracoda). - J. Micropalaeontol. 5 (1), 91-108.

Müller, G. W., 1894. Die Ostracoden des Golfes von Neapel und der angrenzenden Meeresabschnitte. - Fauna Flora Golf. Neapel 21, 1-404.

Teeter, J. W., 1975. Distribution of holocene marine Ostracoda from Belize. - Stud. Geol. 2, 400-499.

Yassini, I. \& Jones, B. G., 1987. Ostracoda in Lake Illawarra: Environmental factors, assemblages and systematics. - Austr. J. mar. freshw. Res. 38, 795-843. 


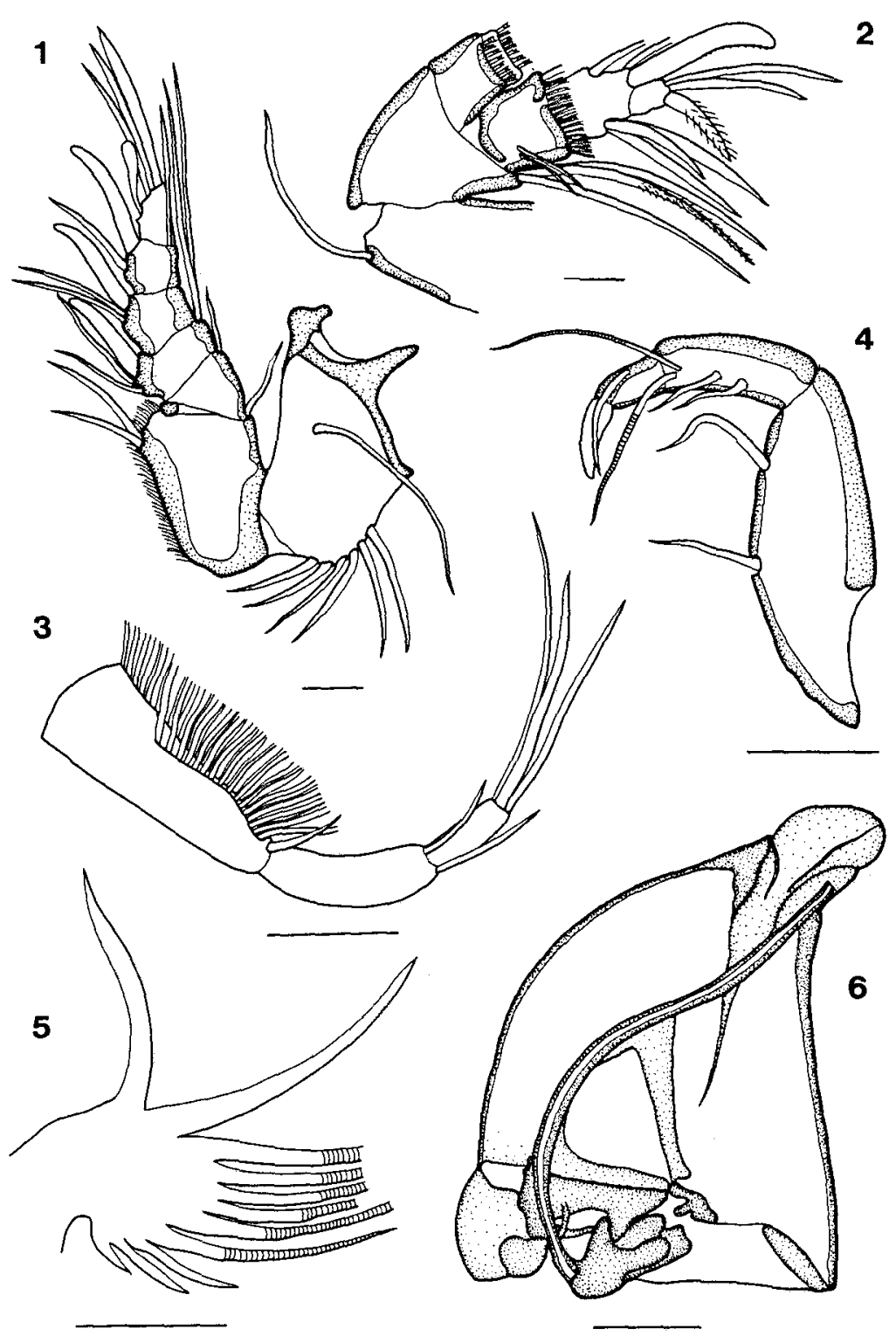

Figs 1-6. Keijcyoidea poikilokosmena sp. n. 1: Au. 2: Aa. 3: Mxu-palp. 4: Pl. 5: Fu. 6: Male copulatory organ (Scales of Figs 1-6 $=0.025 \mathrm{~mm}$ ) 


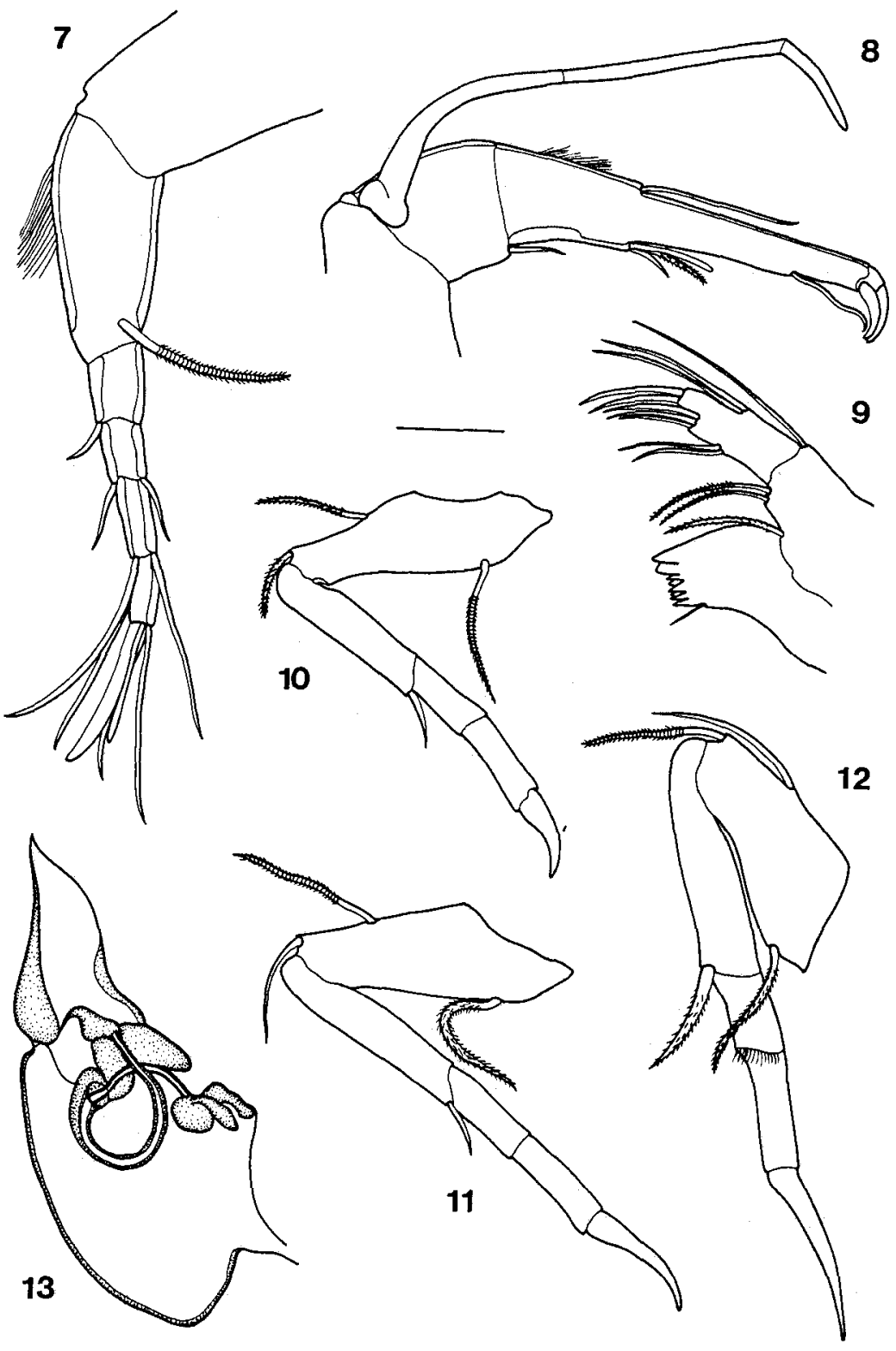

Figs 7-13. ?Corallicythere arcanis sp. n. 7: Au. 8: Aa. 9: Md-palp. 10: P1. 11: P2. 12: P3. 13: Male copulatory organ (Scales of Figs $7-13=0.025 \mathrm{~mm}$ ) 


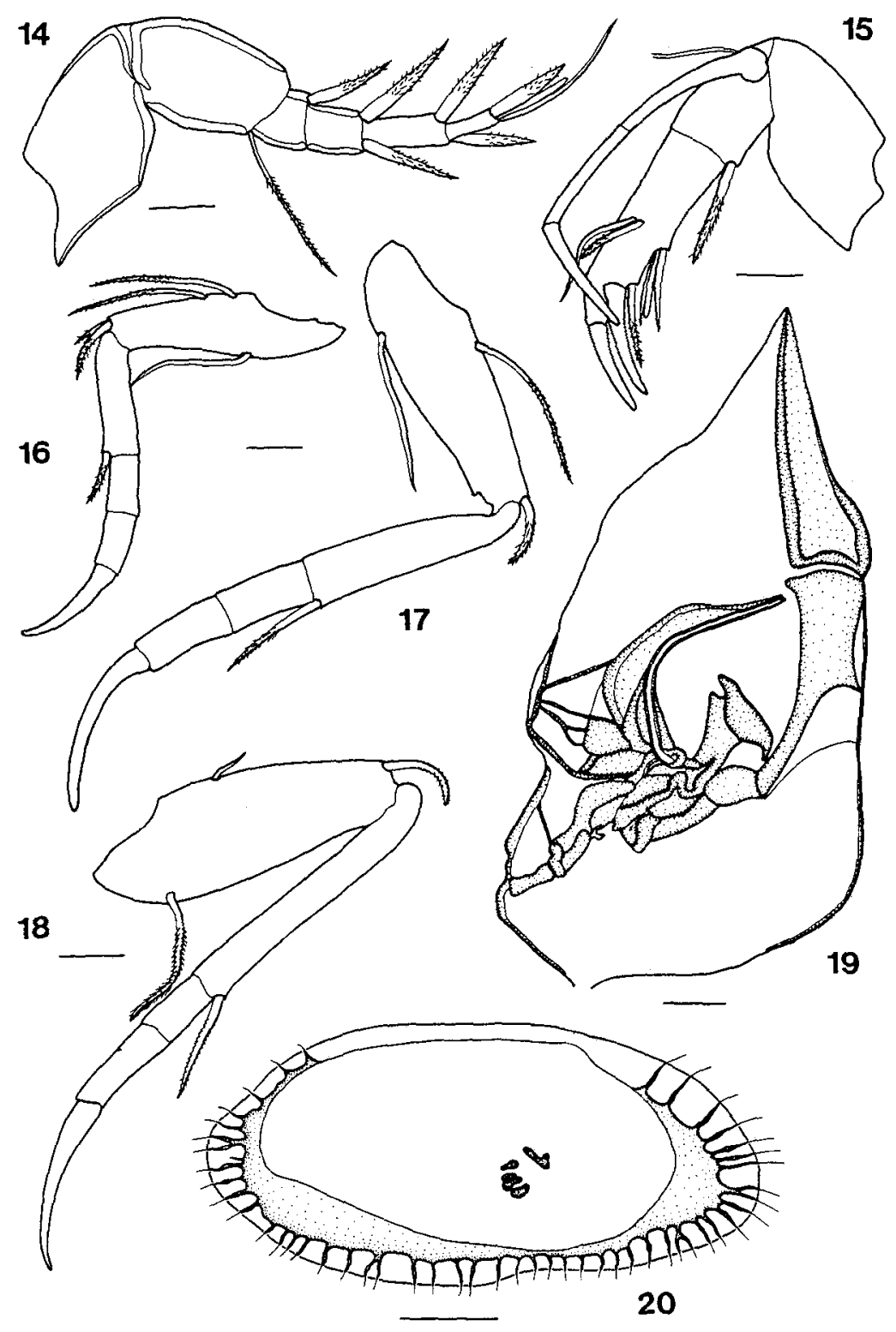

Figs 14-20. Paracytheroma aestatophila sp. n. 14: Au. 15: Aa. 16: P1. 17: P2. 18: P3. 19: Male copulatory organ (Scales of Figs $14-19=0.025 \mathrm{~mm}$ ). 20: LV, inner view (Scale $=0.1 \mathrm{~mm}$ ) 


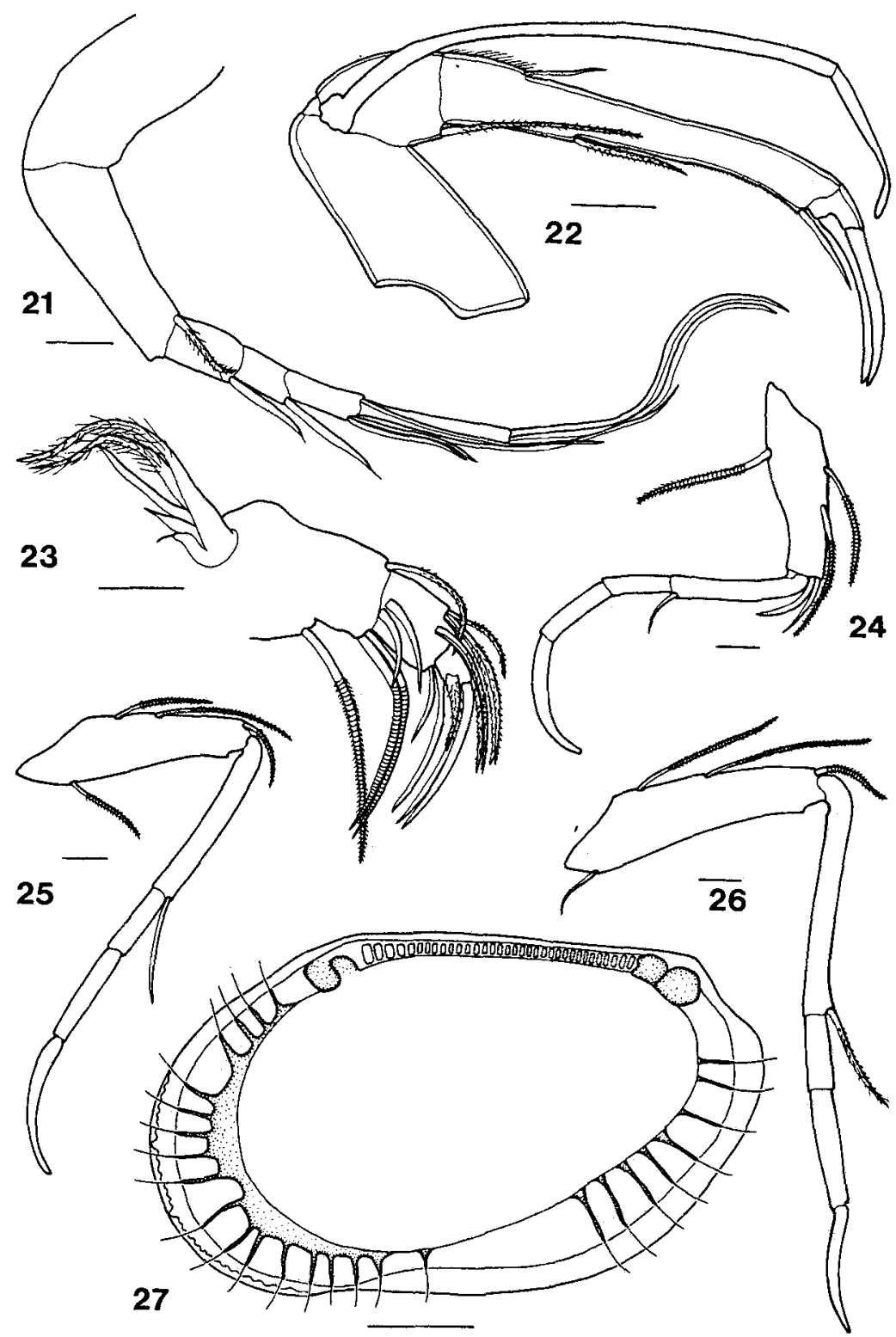

Figs 21-27. Loxoconcha violacea sp. n. 21: Au. 22: Aa. 23: Md-palp. 24: P1. 25: P2. 26: P3 (Scales of Figs $21-26=0.025 \mathrm{~mm}$ ). 27: RV, inner view (Scale $=0.1 \mathrm{~mm}$ ) 


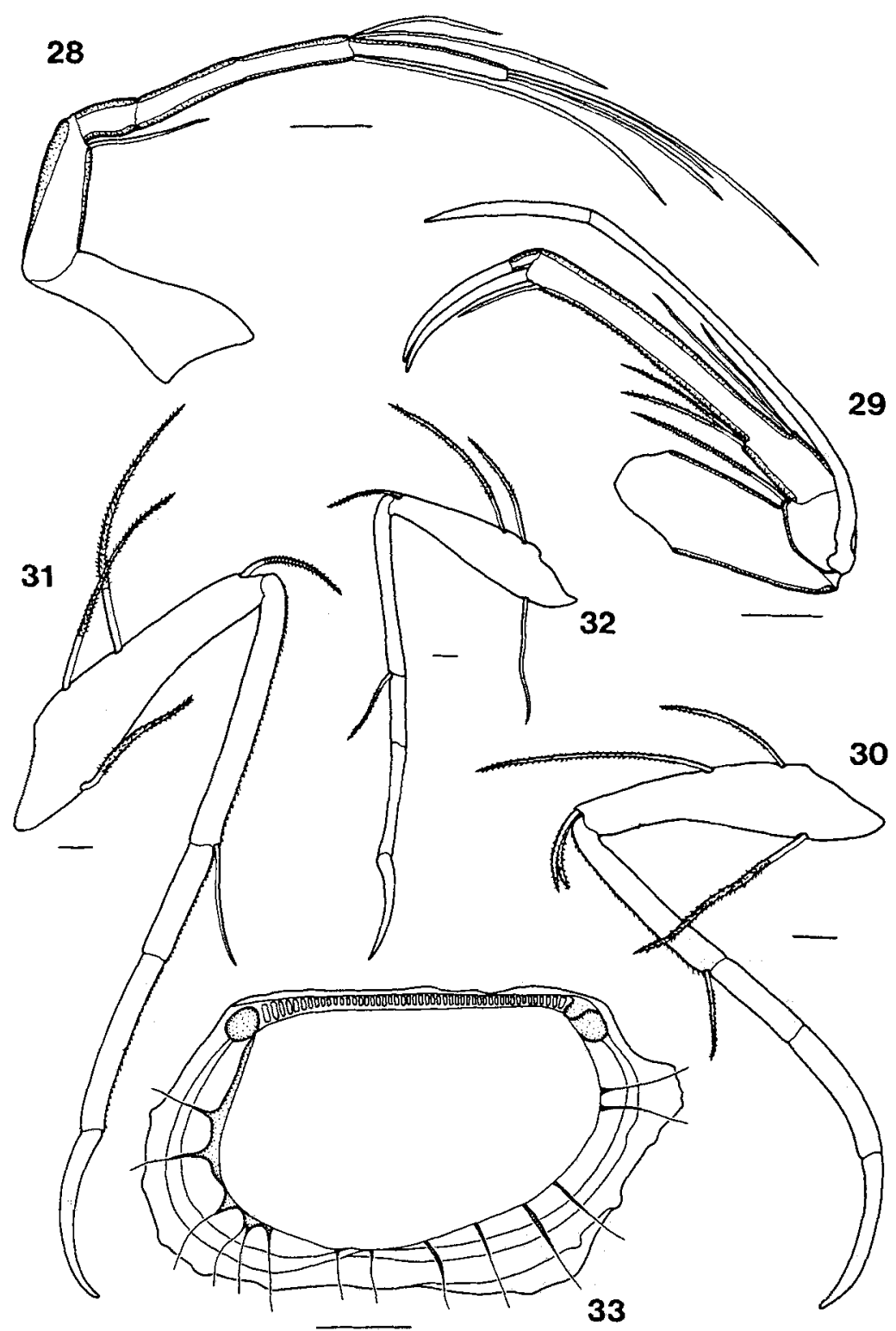

Figs 28-33. Loxoconcha parahuahinéensis sp. n. 28: Au. 29: Aa. 30: P1, 31: P2. 32: P3 (Scales of Figs $28-32=0.025 \mathrm{~mm}$ ). $33: \mathrm{RV}$, inner view (Scale $=0.1 \mathrm{~mm}$ ) 


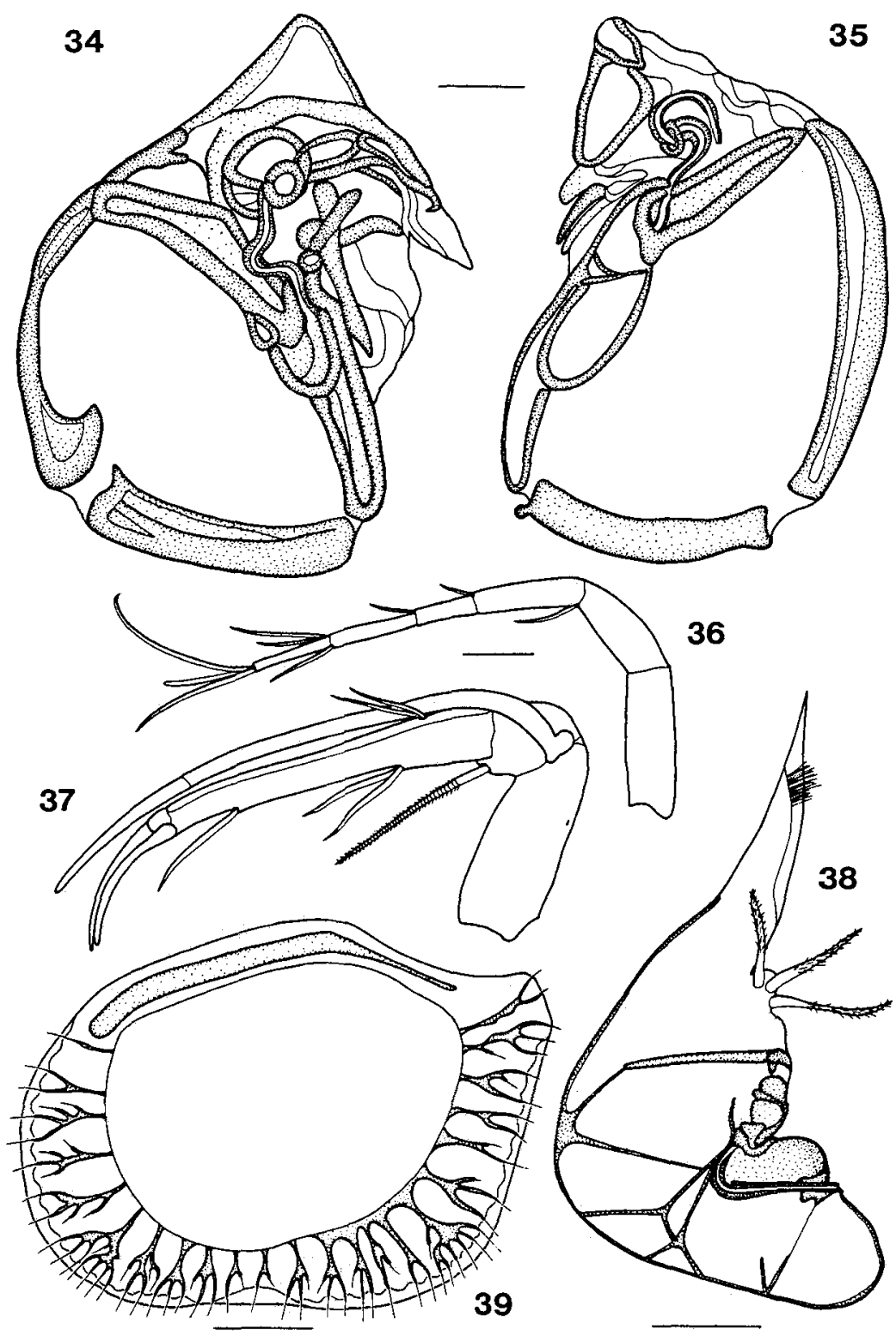

Fig. 34. Loxoconcha violacea sp. n. Male copulatory organ (Scale $=0.025 \mathrm{~mm}$ ) Fig. 35. L. parahuahinéensis sp. n. Male copulatory organ (Scale $=0.025 \mathrm{~mm}$ )

Figs 36-39. Loxoconchella lizardensis sp. n. 36: Au. 37: Aa. 38: Male copulatory organ (Scales of Figs $36-38=0.025 \mathrm{~mm}) .39: \mathrm{LV}$, inner view (Scale $=0.1 \mathrm{~mm}$ ) 


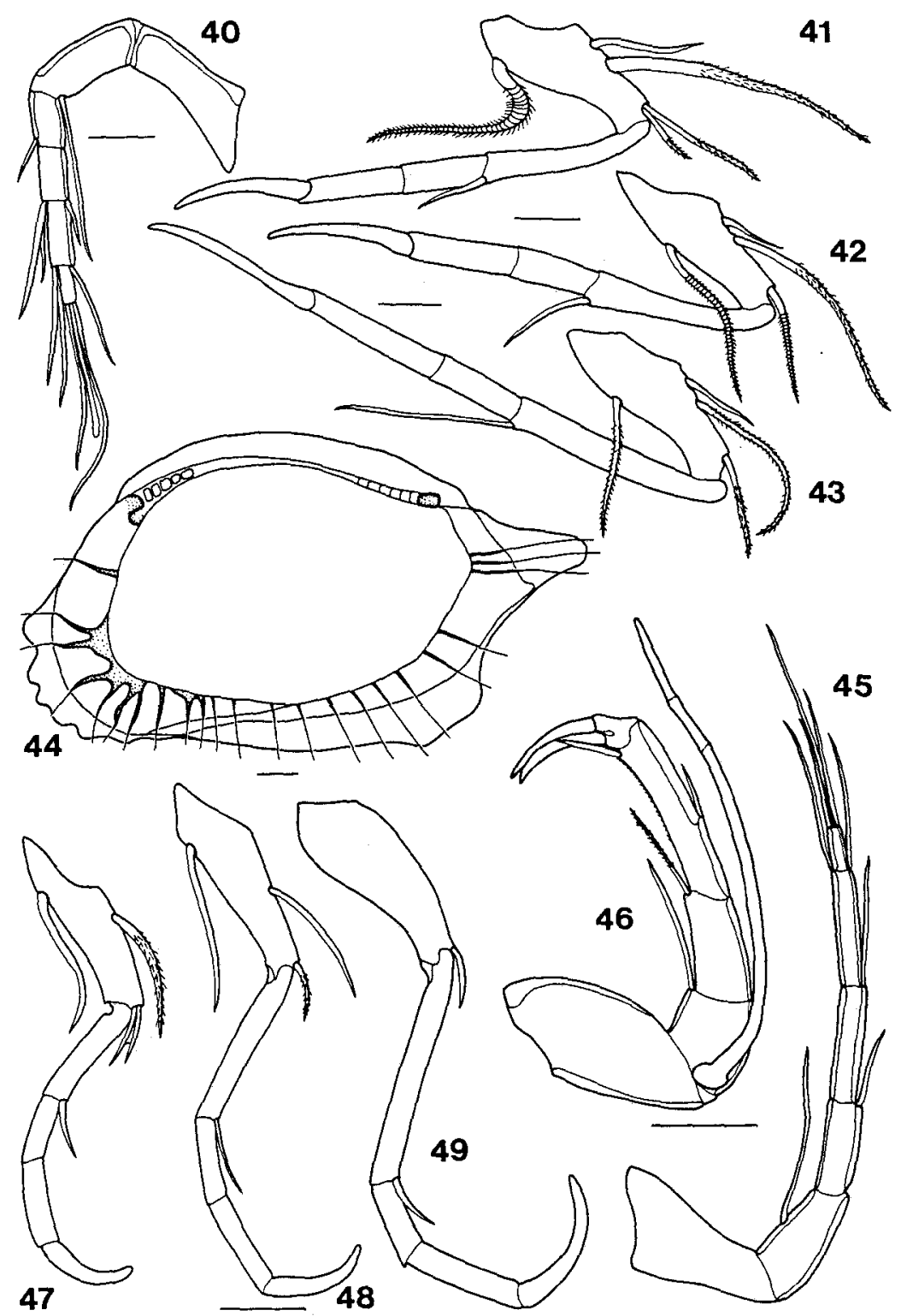

Figs 40-43. Paracytheridea gynaikokratia sp. n. 40: Au. 41: P1. 42: P2. 43: P3 (Scales of Figs $40-43=0.025 \mathrm{~mm}$ )

Figs 44-49. Hemicytherura viridiminor sp, n. 44: LV, inner view. 45: Au, 46: Aa. 47: P1. 48: P2. 49: P3 (Scales of Figs $44-49=0.025 \mathrm{~mm}$ ) 


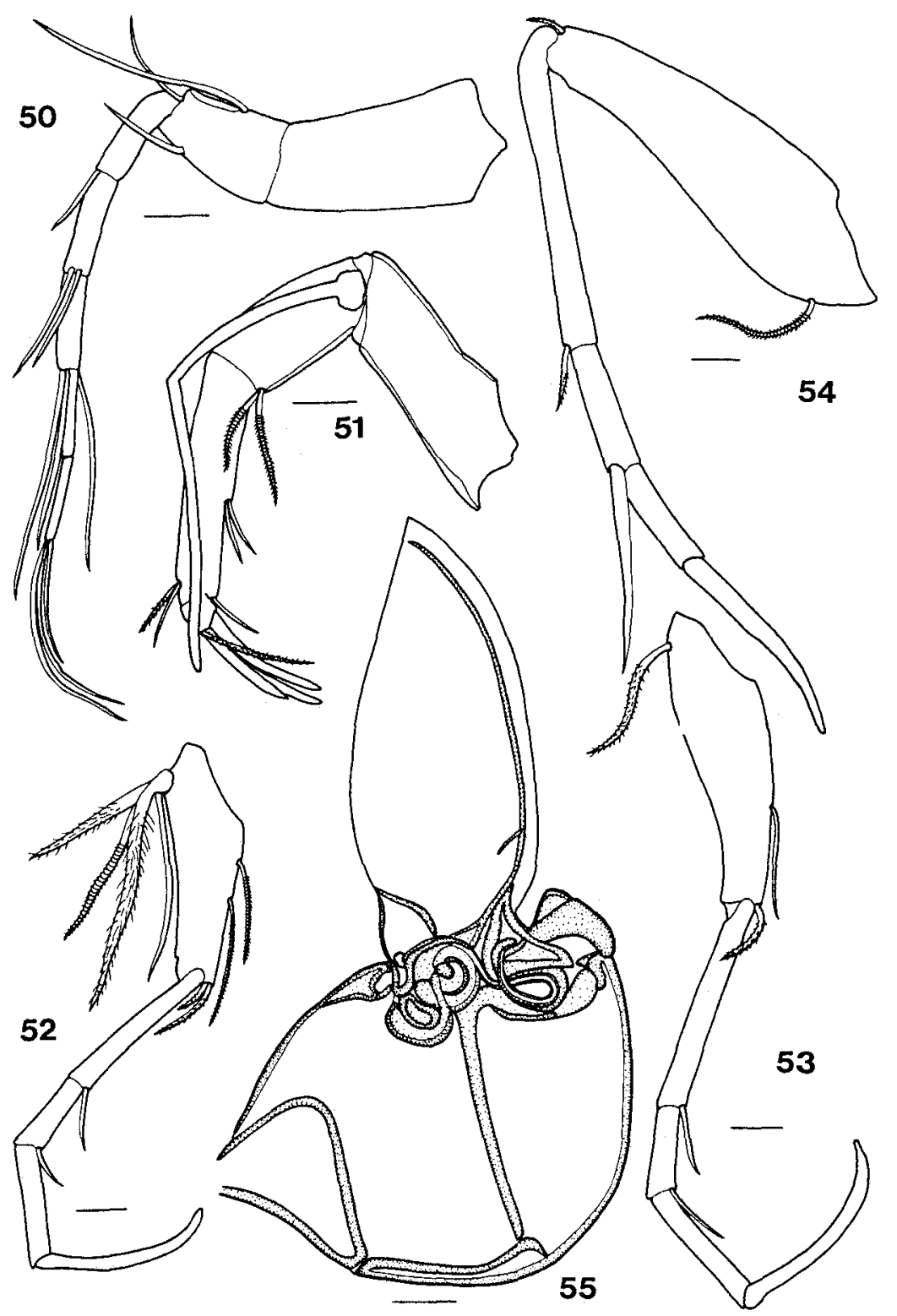

Figs 50-55. Bythocythere arenicola sp. n. 50: Au. 51: Aa. 52: P1. 53: P2. 54: P3. 55: Male copulatory organ (Scales of Figs $50-55=0.025 \mathrm{~mm}$ ) 


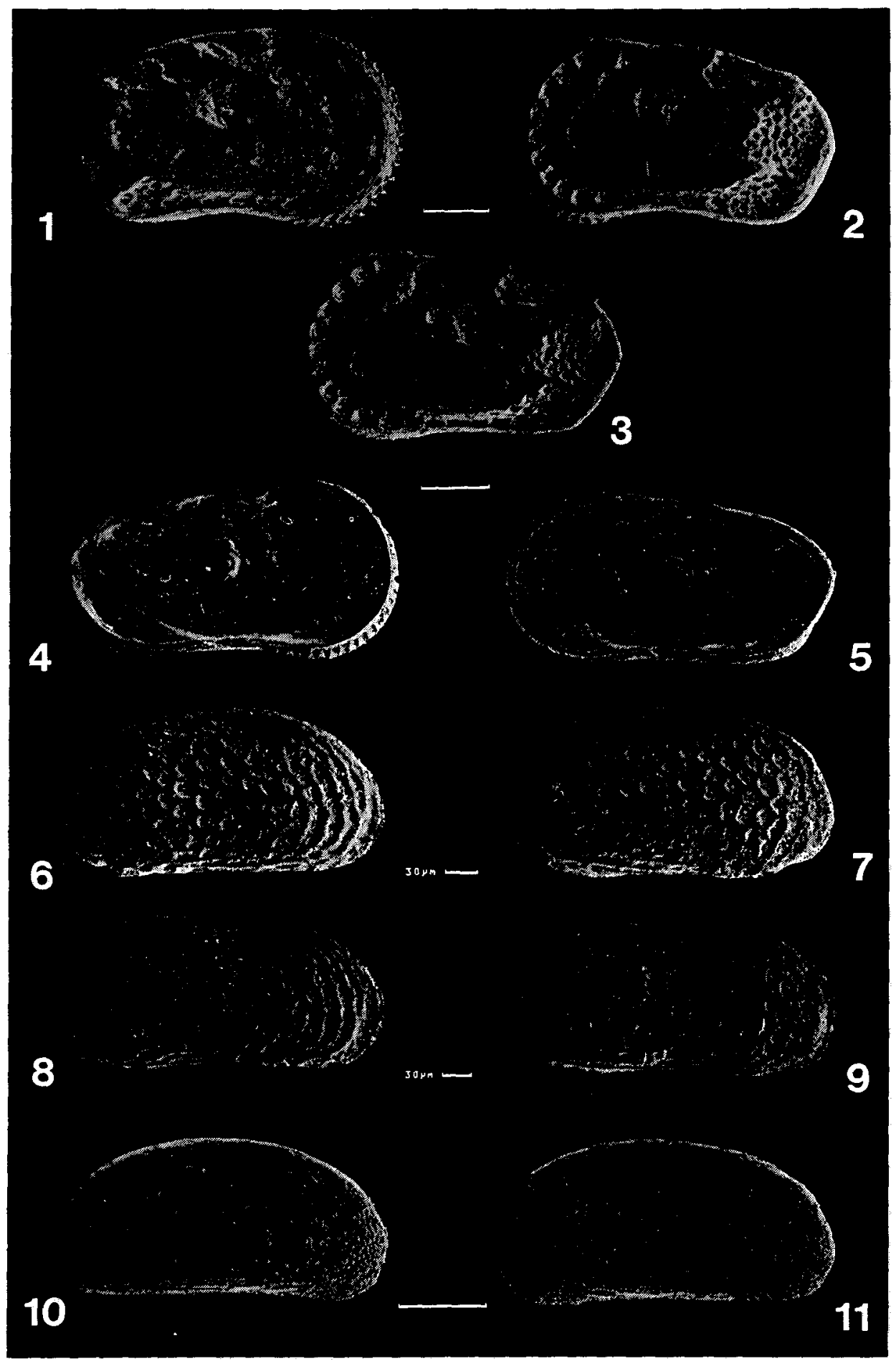

Plate 1. Figs 1-5. Keijcyoidea poikilokosmena sp.n. 1: Male, RV. 2: Male, LV. 3: Female, LV. 4: $\mathrm{LV}$, inner view. 5: RV, inner view

Figs 6-9. Microcytherura aestuaricola Hartmann, 1980. 6: Female, RV. 7: Female, LV. 8: Male, RV. 9: Male, LV

Figs 10-11. ?Corallicythere arcanis sp.n. 10: Female, RV. 11: Female, LV. (Scales $=0.1 \mathrm{~mm}$ ) 


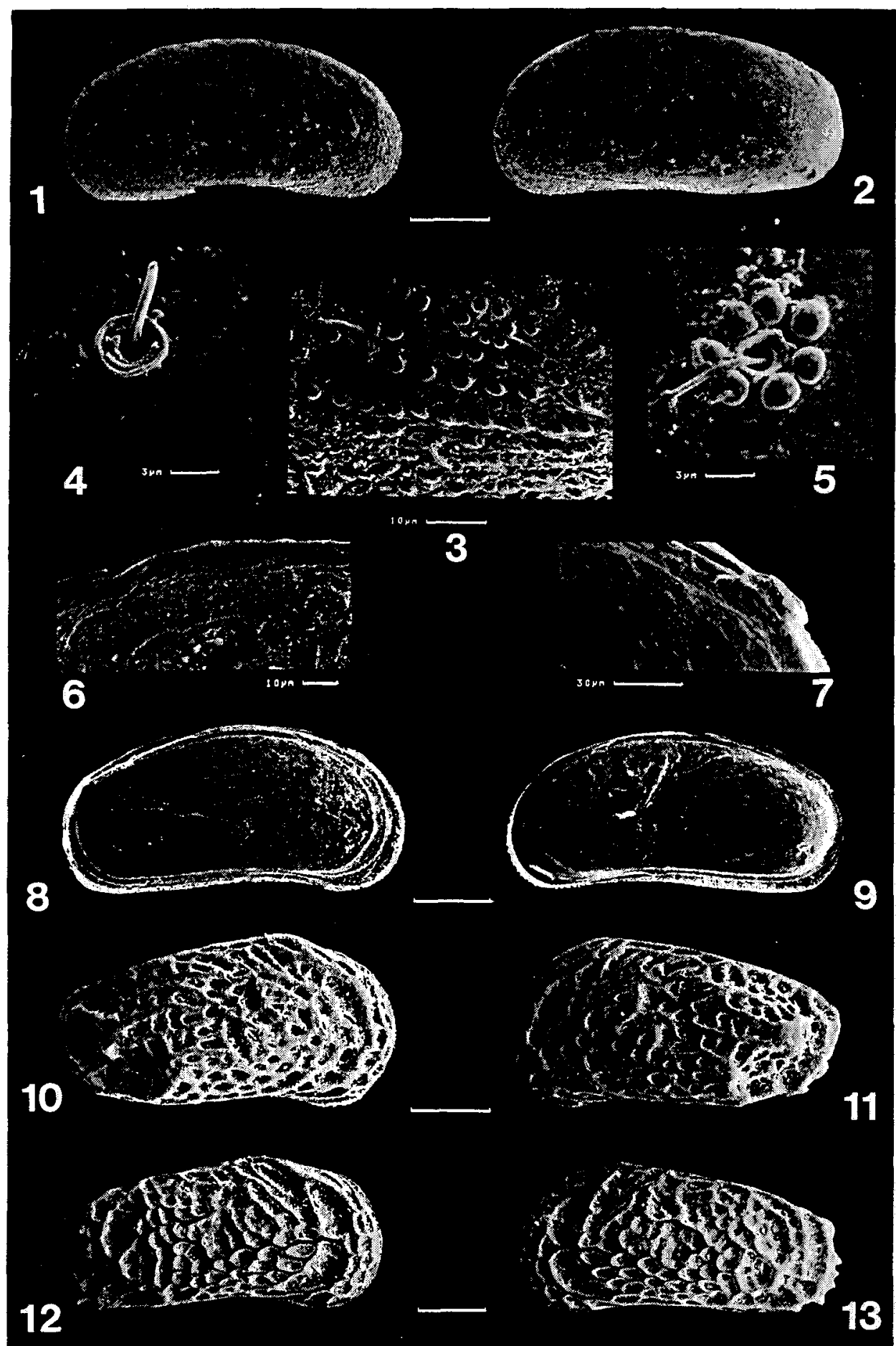

Plate 2. Figs 1-9. ?Corallicythere arcanis sp.n. 1: Male, RV. 2: Male, LV. 3: Sculpture. 4 and 5: Pore canals. 6: Anterior hingement, RV. 7: Posterior hingement. 8: LV, inner view. 9: $\mathrm{RV}$, inner view

Figs 10-11. Morkhovenia inconspicua (Brady, 1880). 10: Female, RV. 11: Female, LV Figs 12-13. Keijia hirundo (Bonaduce, Masoli \& Pugliese, 1976). 12: Female, RV. 13: Fenale, LV

(Scales $=0.1 \mathrm{~mm}$, if not stated otherwise) 


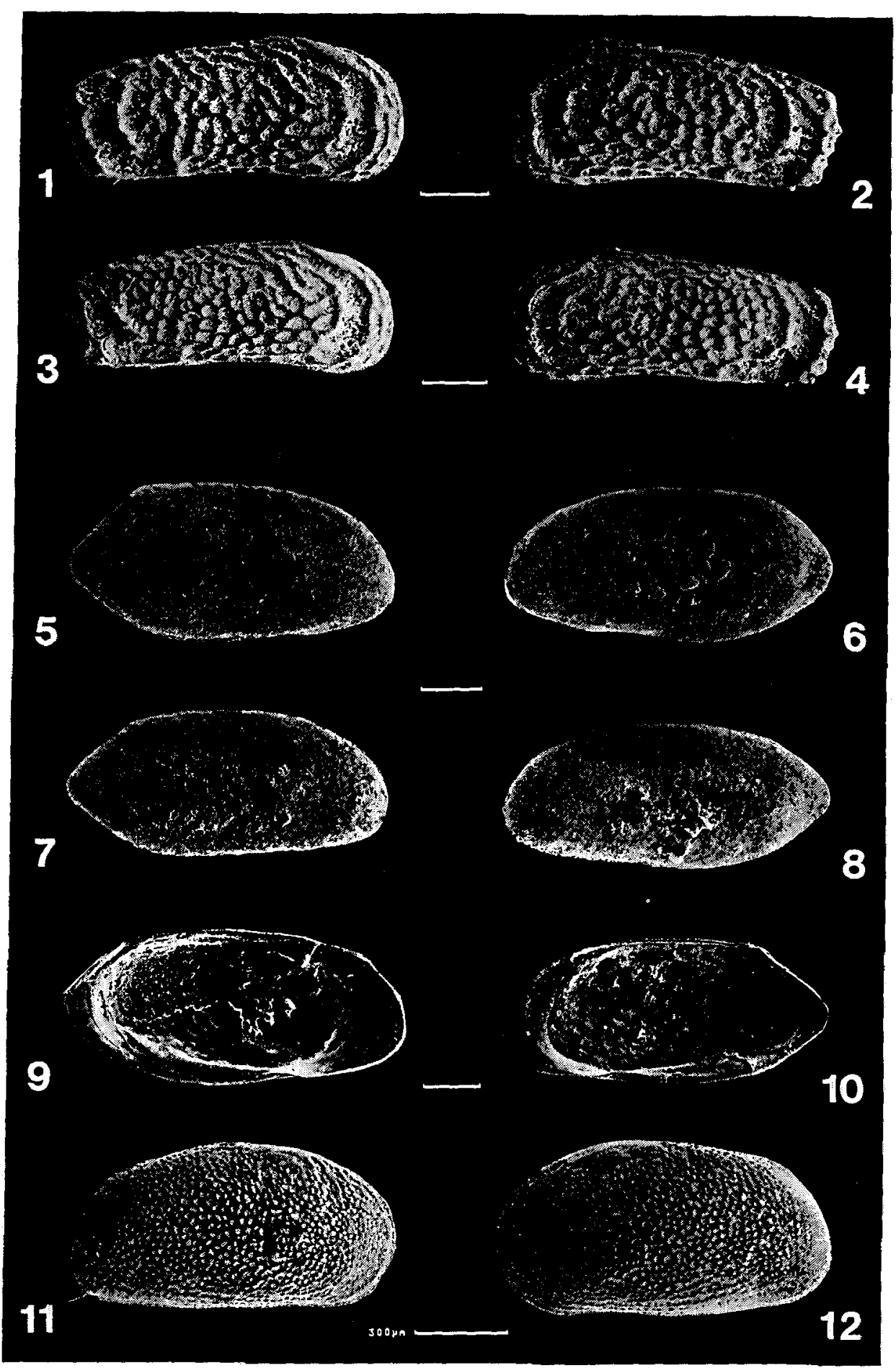

Plate 3. Figs 1-4. Keijia foveata (Hartmann, 1978). 1: Male, RV. 2: Male, LV. 3: Male, RV. 4: Male, LV

Figs 5-10. Paracytheroma aestatophila sp.n. 5: Female, RV. 6: Female, LV. 7: Male, RV. 8: Male, LV. 9: LV, inner view. 10: RV, inner view

Figs 11-12. Cyprideis australiensis Hartmann, 1978. 11: Male, RV. 12: Male, LV (Scales $=0.1 \mathrm{~mm}$ ) 


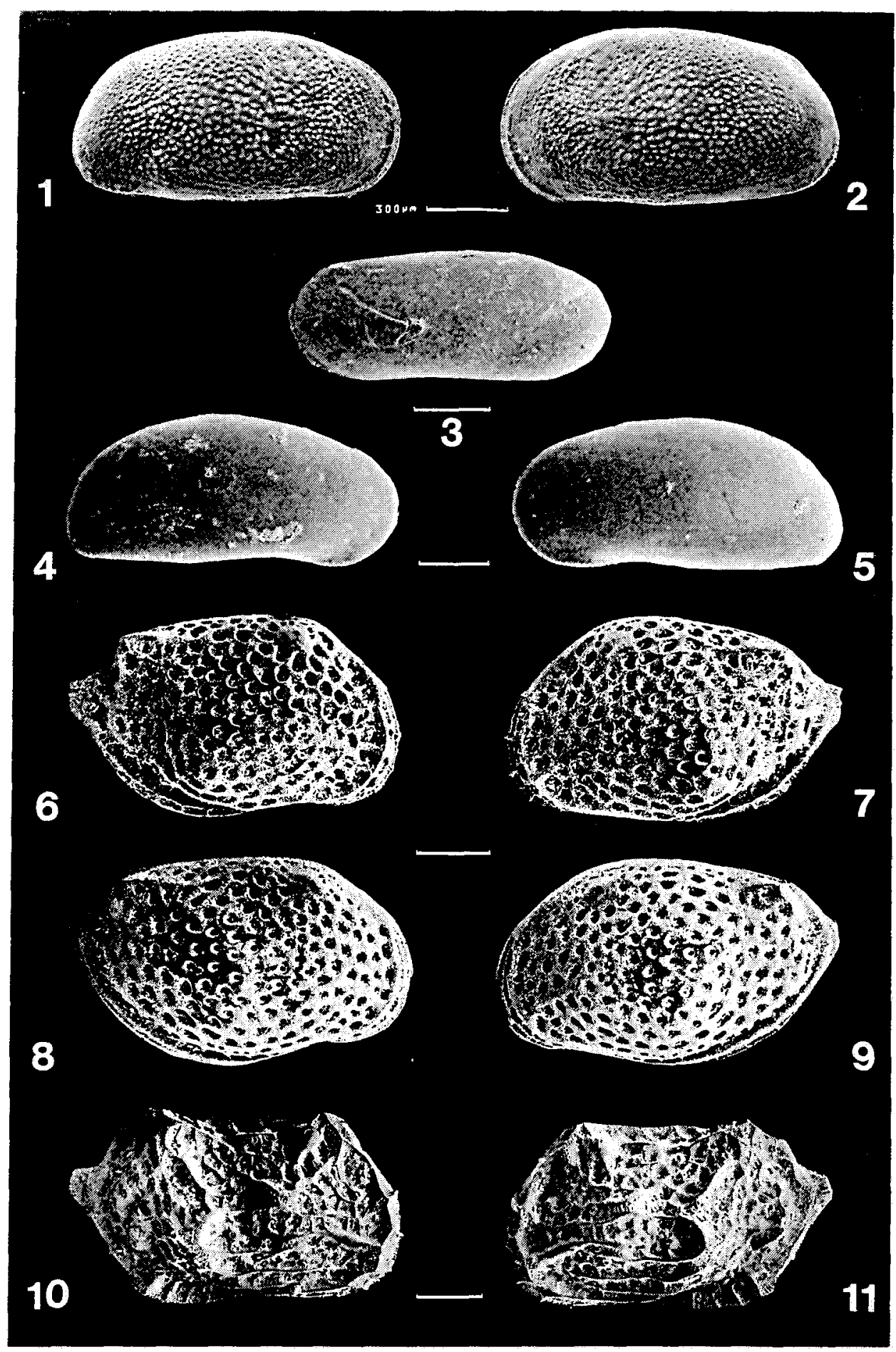

Plate 4. Figs 1-2. Cyprideis australiensis Hartmann, 1978. 1: Female, RV. 2: Female, LV Fig. 3. Parakrithella sp. Lizard 1. Female, LV

Figs 4-5. Parakrithella sp. Lizard 2. 4: Female, RV. 5: Female, LV

Figs 6-9. Loxoconcha georgei Hartmann, 1978. 6: Female, RV. 7: Female, LV. 8: Male, RV. 9: Male, LV

Figs 10-11. Loxoconcha insulaecapricornensis Hartmann, 1981. 10: Female, RV. 11: Female, LV

(Scales $=0.1 \mathrm{~mm}$ ) 


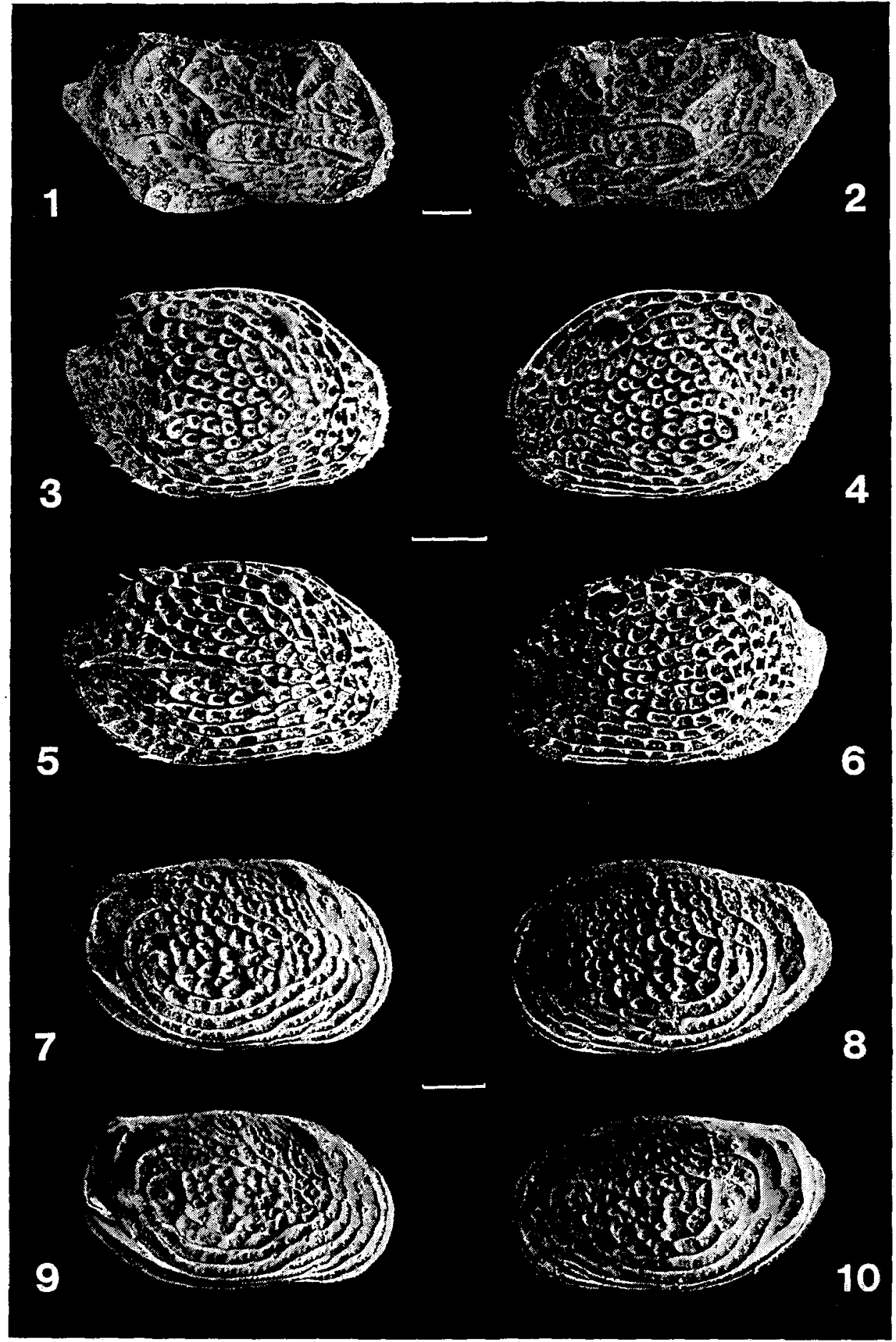

Plate 5. Figs 1-2. Loxoconcha insulaecapricornensis Hartmann, 1981. 1: Male, RV: 2: Male, LV Figs 3-6. L. heronislandensis Hartmann, 1981. 3: Female, RV. 4: Female, LV. 5: Male, RV. 6: Male, LV

Figs 7-10. L. violacea sp. n. 7 : Female, RV. 8: Female, LV. 9: Male, RV. 10: Male, LV (Scales $=0.1 \mathrm{~mm}$ ) 


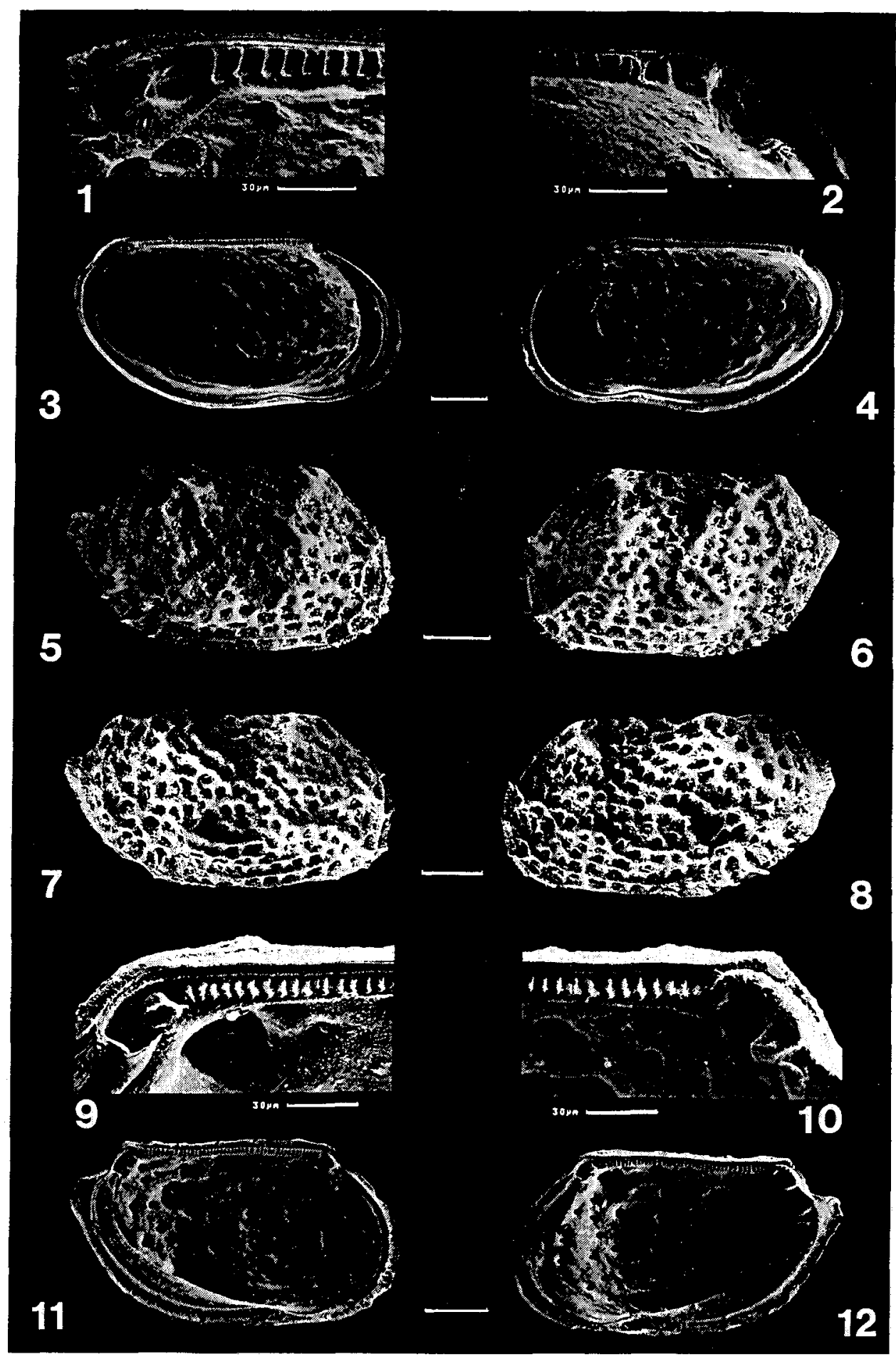

Plate 6. Figs 1-4. Loxoconcha violacea sp. n. 1: RV, anterior hingement. 2: RV, posterior hingement: 3: $\mathrm{LV}$, inner view. 4: $\mathrm{RV}$; inner view

Figs 5-12. L. parahuahinéensis sp. n. 5: Female, RV. 6: Female, LV. 7: Male, RV. 8: Male, LV. 9: RV, anterior hingement. 10: RV, posterior hingement. 11: LV, inner view, 12: RV, inner view

(Scales $=0.1 \mathrm{~mm}$, if not stated otherwise) 


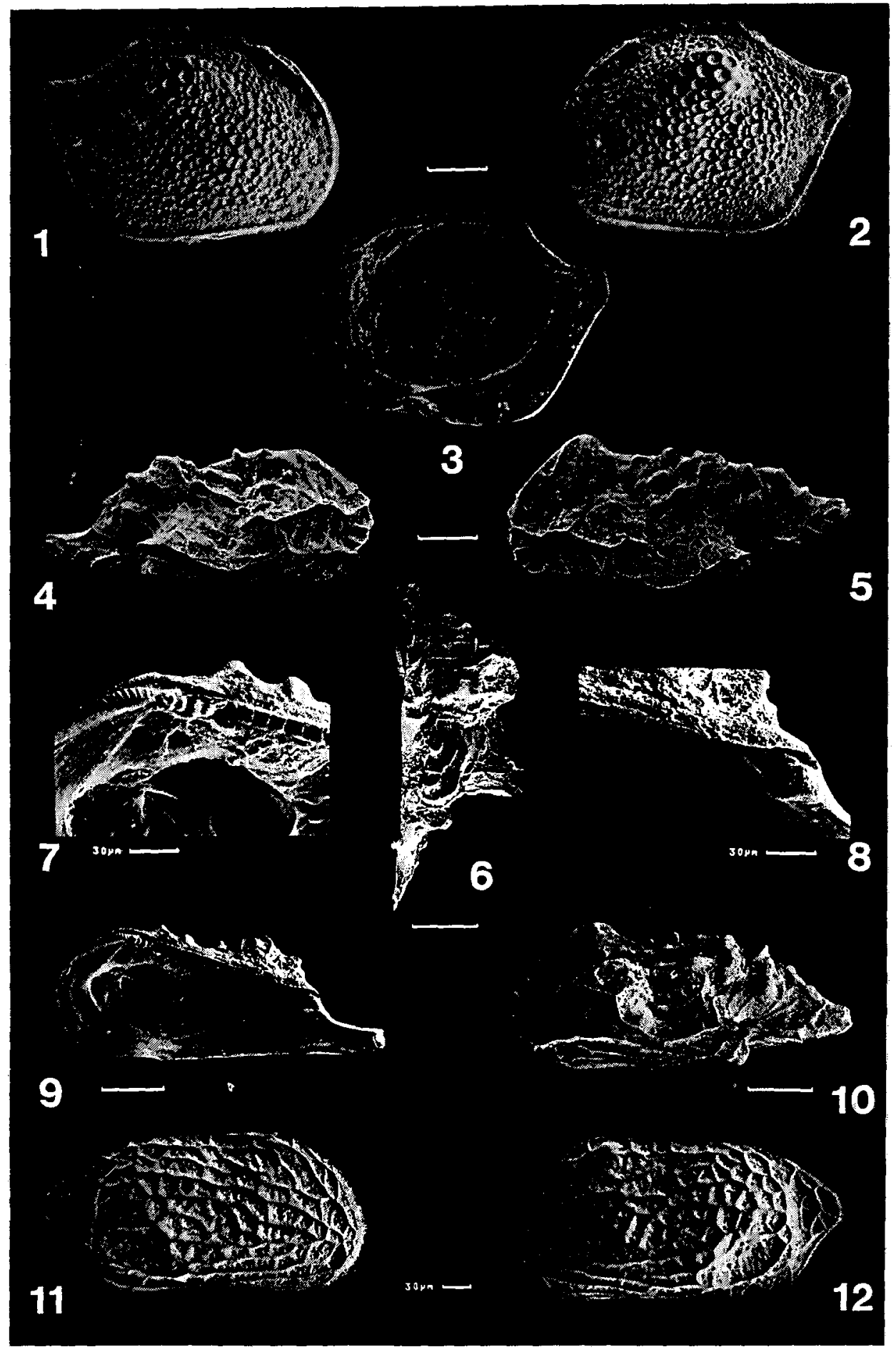

Plate 7. Figs 1-3. Loxoconchella lizardensis sp. n. 1: Female, RV. 2: Female, LV. 3: RV, inner view Figs 4-9. Paracytheridea gynaikokratia sp.n. 4: Female, RV. 5: Female, LV. 6: Female, dorsal view. 7: RV, anterior hingement, 8: RV, posterior hingement. 9: RV, inner view Fig. 10. Parakrithella sp. Lizard 1. Female, LV

Figs 11-12. Cytherura cf. densuireticulata Hartmann, 1978. 11: Female, RV. 12: Female, LV (Scales $=0.1 \mathrm{~mm}$, if not stated otherwise) 


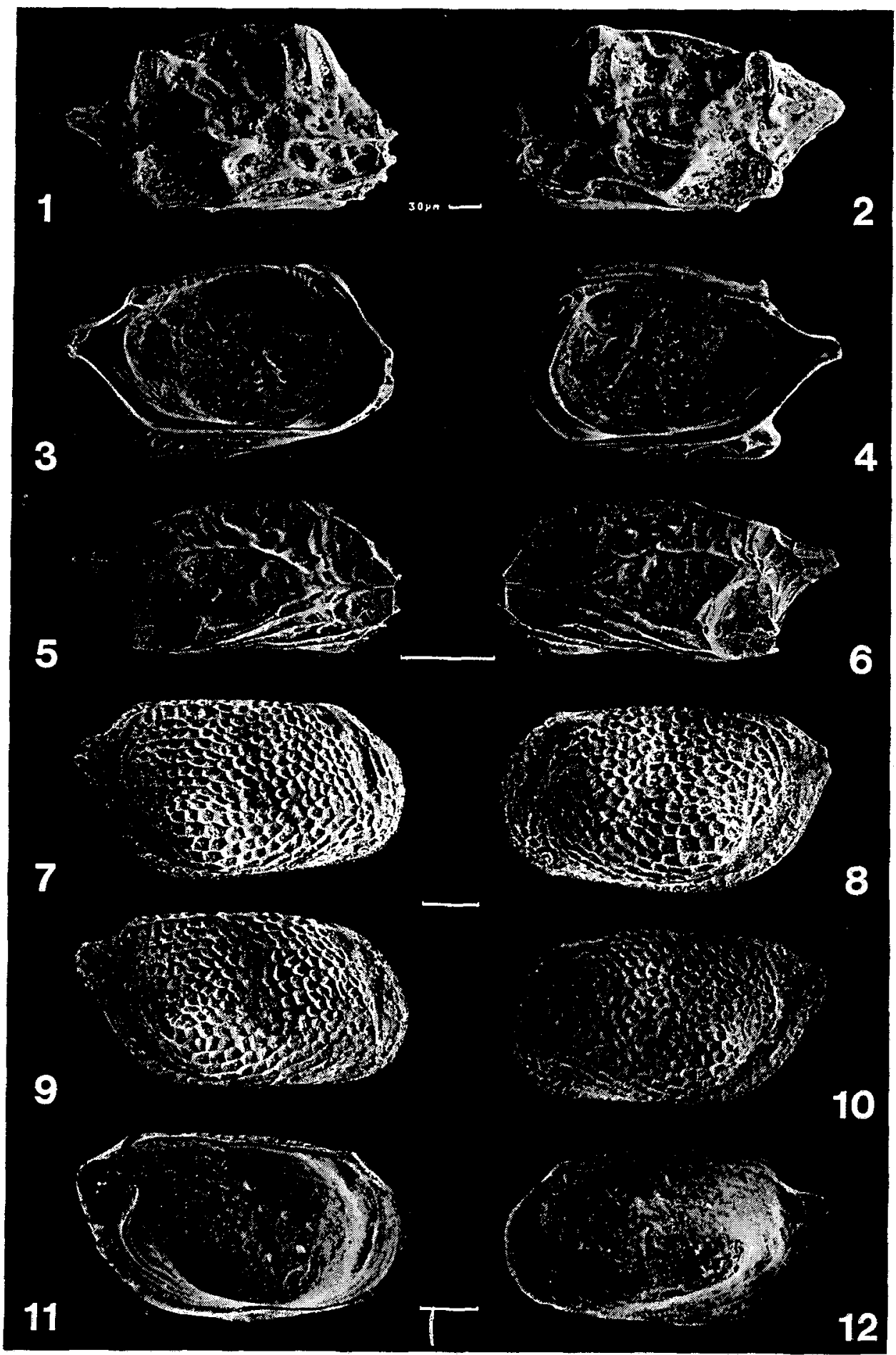

Plate 8. Figs 1-4. Hemicytherura viridiminor sp. n. 1: Female, RV. 2: Female, LV. 3: LV, inner view. 4: $\mathrm{RV}$, inner view

Figs 5-6. Semicytherura sp. Lizard 1. 5: Female, RV. 6: Female, LV

Figs 7-12. Bythocythere arenicola sp.n. 7: Female, RV. 8: Female, LV. 9: Male, RV. 10: Male, LV. 11: LV, inner view. 12: RV, inner view

$($ Scales $=0.1 \mathrm{~mm})$ 